University of Pennsylvania Carey Law School

Penn Law: Legal Scholarship Repository

Faculty Scholarship at Penn Law

2017

\title{
Choice-of-law Rules for Secured Transactions: An Interest-Based and Modern Principles-Based Framework for Assessment
}

Charles W. Mooney Jr.

University of Pennsylvania Carey Law School

Follow this and additional works at: https://scholarship.law.upenn.edu/faculty_scholarship

Part of the Banking and Finance Law Commons, Commercial Law Commons, Conflict of Laws Commons, Law and Economics Commons, Other Business Commons, Policy Design, Analysis, and Evaluation Commons, and the Secured Transactions Commons

\section{Repository Citation}

Mooney, Charles W. Jr., "Choice-of-law Rules for Secured Transactions: An Interest-Based and Modern Principles-Based Framework for Assessment" (2017). Faculty Scholarship at Penn Law. 1776. https://scholarship.law.upenn.edu/faculty_scholarship/1776

This Article is brought to you for free and open access by Penn Law: Legal Scholarship Repository. It has been accepted for inclusion in Faculty Scholarship at Penn Law by an authorized administrator of Penn Law: Legal Scholarship Repository. For more information, please contact PennlawIR@law.upenn.edu. 


\title{
Choice-of-law rules for secured transactions: an interest-based and modern principles-based framework for assessment
}

Charles W. Mooney Jr.*

\begin{abstract}
This article addresses the codification of the law applicable to the creation, perfection, priority, and enforcement of security rights in movable assets-the relevant 'choice-oflaw' or 'private international law' rules (STCOL rules) for secured transactions. The STCOL rules are a core element of secured transactions law. The article offers a framework for the assessment of existing and proposed future rules and their relationship to the substantive law of secured transactions, thereby illuminating an underdeveloped and under-theorized area of the law. The framework takes account of the emerged and emerging modern principles of secured transactions law, as epitomized by the recently completed UNCITRAL Model Law on Secured Transactions. Application of the framework involves an analysis of the interests of the various stakeholders affected by secured transactions law-assignees (secured creditors), assignors (grantors), third-party obligors (such as obligors on receivables owed to grantors), other third parties such as an assignor's creditors, transferees, and insolvency representative, and States that enact and apply secured transactions laws, including the STCOL rules. It considers the manner and extent to which STCOL rules take account of the stakeholder interests and serve the substantive rules of secured transactions laws.
\end{abstract}

\section{Introduction}

This article examines the law applicable to secured transactions and, in particular, the codification of the law applicable to the various aspects of secured transactions. It draws both inspiration and guidance from the 2016 UNCITRAL Model

* Professor of Law, University of Pennsylvania Law School; Visiting Professor of Law, Gakushuin University Faculty of Law (2017), 3501 Chestnut Street Philadelphia, PA 19104, USA. Tel: 610-952-0675; Email: cmooney@law.upenn.edu. I wish to thank John Wilson for helpful comments on an earlier draft of this article as well as participants at the United Nations Commission on International Trade Law (UNCITRAL) Fourth International Colloquium on Secured Transactions, 15-17 March 2017, Vienna. I also express my appreciation to Penn Law and Gakushuin University for generous support during the preparation of this article. 
Law on Secured Transactions (Model Law). ${ }^{1}$ Choice-of-law rules lie at the heart of the emerged and emerging modern principles of secured transactions law (which I refer to here as the Modern Principles ${ }^{2}$ ) for personal property (movable assets). ${ }^{3}$ The penumbra of these secured transactions choice-of-law rules (STCOL rules) extends beyond secured transactions law per se to the law of property (real) rights more generally. Yet, the bases for these STCOL rules and their relationship to related substantive legal doctrine remain somewhat underdeveloped and under-theorized.

This article seeks to remedy this situation or at least to take steps towards that end. It situates the STCOL rules as fundamental components of secured transactions law and central to understanding the normative principles and factual assumptions that underpin that important body of law. Its principal contribution is to offer a framework for assessing the existing STCOL rules and for the codification of such rules in the future. The framework is based on the interests of stakeholders that participate in, or are affected by, secured transactions and the Modern Principles. These stakeholders include not only parties to, and affected by, transactions but also the States that would adopt and apply the STCOL rules. This framework also illuminates the factual determinations and assumptions necessary to apply the framework and to evaluate these choice-of-law rules, thereby providing measurable standards for their assessment.

The scope of this article does not permit an exhaustive analysis of the STCOL rules for every aspect of secured transactions and for every type of asset. But it does aspire to outline a framework and methodology for guiding future work in this important area of investigation and codification. This framework can be tested here only through its application and analysis. And this application necessarily produces an assessment of STCOL rules and conclusions, albeit tentative ones, as to the rules that should be adopted. But, this application must be based on the essential factual assumptions concerning the interests of stakeholders and their relationships to the Modern Principles. With this in mind, the conclusions that I reach here on the merits of various existing and potential STCOL rules represent only a modest contribution to the literature based on one person's judgments. The more important offering is the framework for assessment-the identification of the questions to be asked and answered.

By focusing on the interests of stakeholders in secured transactions and the Modern Principles, the framework proposed here generally is compatible with the

1 United Nations Commission on International Trade Law (UNCITRAL) Model Law on Secured Transactions (1 July 2016), http://www.uncitral.org/pdf/english/texts/security/ML_ST_E_ebook. pdf (Model Law). The Model Law was inspired by its predecessor, UNCITRAL Legislative Guide on Secured Transactions (2007), http://www.uncitral.org/pdf/english/texts/security-lg/e/09. 82670_Ebook-Guide_09-04-10English.pdf (Guide). In July 2017 UNCITRAL approved the draft Guide to Enactment of the UNCITRAL Model Law on Secured Transactions, which will be published shortly (see A/CN.9/914 and Add. 1-6).

2 For a summary description of the Modern Principles, see pp 5-6 below.

3 For present purposes personal property or movable assets generally refers to all tangible and intangible property other than immovable property (real estate, land and buildings, etc.). 
'most significant relationship' approach of the Restatement (Second) of Conflict of Laws (Restatement Second), ${ }^{4}$ guided by the principles of its section $6 .{ }^{5}$ However, the project here is not to consider how a court might employ the principles of section 6 to determine the applicable law but, instead, to consider the role of a lawmaker (legislator or regulator) in the process of codifying the STCOL rules. While the factors listed in section 6 provide flexibility (perhaps too much so, according to some ${ }^{6}$ ), the stakeholders in the secured transactions setting require certainty from the rules, even at the cost of being over- or under-inclusive in particular factual scenarios.

At the outset, it is useful to provide a brief explication of the terminology used in this article. The prototypical secured transaction involves an assignor of an interest, a security interest or security right, ${ }^{7}$ in personal property, the encumbered asset, to an assignee for the purpose of securing an obligation - the secured obligation, which typically (but not necessarily) is an obligation of the assignor to the assignee. The assignor often may be referred to elsewhere as a grantor ${ }^{8}$ or debtor, ${ }^{9}$ and the assignee referred to as a secured creditor $^{10}$ or secured party. ${ }^{11}$ The more neutral (assignor/assignee) nomenclature is used here because in some secured transactions the assignor is an outright seller of the encumbered asset to an assignee that is the buyer of the encumbered asset. In these outright transfer

4 Restatement (Second) of Conflict of Laws (American Law Institute 1977).

5 See, e.g., ibid s 188(1) (rights and duties in contract determined by law of State with 'most significant relationship to the transaction and the parties under the principles stated in $\$ 6^{\prime}$ ). Restatement Second section 6 provides:

(1) A court, subject to constitutional restrictions, will follow a statutory directive of its own state on choice of law.

(2) When there is no such directive, the factors relevant to the choice of the applicable rule of law include (a) the needs of the interstate and international systems, (b) the relevant policies of the forum, (c) the relevant policies of other interested states and the relative interests of those states in the determination of the particular issue, (d) the protection of justified expectations, (e) the basic policies underlying the particular field of law, (f) certainty, predictability and uniformity of result, and (g) ease in the determination and application of the law to be applied.

6 See, e.g., Friedrich K Juenger, 'A Third Conflicts Restatement?' (2000) 75 Indiana Law Journal 403, 410 (noting Restatement Second was 'vague and unprincipled' and allowed courts to 'select ... rules of decision which they found most useful', which was 'the principal reason why judges like it and academics detest it').

7 The remainder of the essay refers to a 'security right', the defined term used in the Model Law. 'Security right' means:

(i) A property right in a movable asset that is created by an agreement to secure payment or other performance of an obligation, regardless of whether the parties have denominated it as a security right, and regardless of the type of asset, the status of the grantor or secured creditor, or the nature of the secured obligation; and

(ii) The right of the transferee under an outright transfer of a receivable by agreement.

Model Law art 2(kk). See also United States Uniform Commercial Code (UCC) 1-201(b)(35)

(defining 'security interest'); Ontario Personal Property Security Act, RSO 1990, c. P.10

(OPPSA) 1(1) (defining 'security interest').

8 This is the term used in the Model Law. Model Law art 2(o).

9 This is the term used in UCC Article 9. UCC 9-102(a)(28).

10 This is the term used in the Model Law. Model Law art 2(ff).

11 This is the term used in UCC Article 9. UCC 9-102(a)(73). 
transactions, there is no 'secured' obligation (and, thus, no debtor, 'secured' creditor, or 'secured' party). Instead, there is a transfer of complete ownership. These outright transfer secured transactions typically involve an encumbered asset that is a right to payment owed by a third party, a third-party obligor, to the assignor and the sale of that right to payment to the assignee. Such a right to payment is commonly referred to as the assignor's receivable.

The STCOL rules supply the applicable law to the various steps or components of secured transactions. The first component (but not necessarily temporally so, in a transactional context) is the creation of the security right, which encompasses the validity, effectiveness, and enforceability of the security right as between the assignor and assignee. A second is the perfection of the security right, which refers to the effectiveness of the security right as against third parties, such as the general creditors of the assignor, a judgment creditor of the assignor, and the assignor's insolvency representative (for example, trustee in bankruptcy or insolvency administrator). A third component is the priority of the security right, which refers to its ranking as among competing interests in the same item of property.

A final element of a secured transaction is the enforcement of the security right. This refers to the process through which the assignee resorts to the encumbered asset for acquiring and allocating value towards the satisfaction of the secured obligation. For goods, ${ }^{12}$ this typically involves the assignee's disposition (for example, sale) of the encumbered asset and application of the net proceeds towards satisfaction of the secured obligation. For other types of encumbered assets, however, enforcement involves another element-enforcement of the encumbered asset itself against the third-party obligor owing performance under the encumbered asset. Such third party-obligation assets (TPO assets) include receivables, mentioned above, as to which the third-party obligor may be referred to as a debtor of the receivable ${ }^{13}$ or an account debtor. ${ }^{14}$ TPO assets also include negotiable instruments, negotiable documents (such as warehouse receipts and bills of lading, the obligor being the issuer of the document), securities (both certificated and uncertificated, the obligor being the issuer of the security), and the rights of an account holder in respect of a securities credited to a securities account maintained with a securities intermediary (such as a stockbroker or bank, the obligor being the intermediary). Figure 1 illustrates an assignment of TPO assets and identifies the relevant obligors. ${ }^{15}$

12 The Model Law does not define or use the term 'goods', which is borrowed here from North American law. See UCC 9-102(a)(44) (defining 'goods' in part as 'all things that are movable when a security interest attaches', but excluding all forms of intangible property and also property otherwise defined in UCC Article 9); OPPSA 1(1) (defining 'goods'). The Model Law defines 'tangible asset' as 'any tangible movable asset'. Model Law art 2( $l l)$. The definition provides that except as used in provisions dealing with what we commonly understand to be goods (e.g., the provisions on a commingled mass or product and acquisition financing), 'the term includes money, negotiable instruments, negotiable documents and certificated non-intermediated securities'. Ibid.

13 This is the term used in the Model Law. Model Law art 2(i).

14 This is the term used in United States Uniform Commercial Code (UCC) Article 9. UCC 9-102(a)(3).

15 There are other types of third-party-obligation assets (TPO) assets not mentioned in Figure 1. But Figure 1 identifies the major types of TPO asset and third-party obligors and is sufficient to support the discussion of the STCOL rules addressed here. 
Obligors on TPO Collateral: (i) debtor or account debtor on receivable, (ii) person obligated on negotiable instrument, (iii) issuer/bailee on document of title, (iv) issuer of certificated or uncertificated security, (v) securities intermediary for securities account

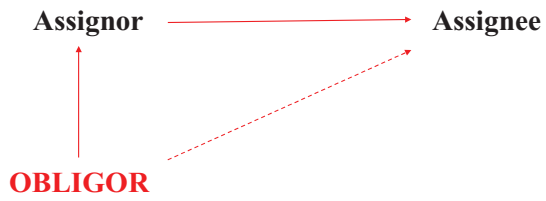

Figure 1. Assignment of TPO Collateral

The Model Law and its direct ancestors (or close cousins, depending on one's perspective), Article 9 of the Uniform Commercial Code (UCC), and the various personal property security acts (PPSAs) adopted by Canadian provinces ${ }^{16}$ (together, sometimes referred to here as North American law or laws) epitomize the 'modern principles' of secured transactions law to which I refer. While no State has yet adopted the Model Law as such, it embraces (as does North American law) principles that are widely reflected in other model laws, ${ }^{17}$ in other secured transactions 'reforms' that have been adopted by many States over recent years, ${ }^{18}$ and that are currently being considered by other States. ${ }^{19}$ Of course, disagreements

16 See, e.g., OPPSA. Concerning choice-of-law rules, OPPSA is typical of the Canadian Provincial PPSA. See Deborah S Grieve, 'Cross-Border Security Interests: Choice of Law in Canada' (2011) 44 Uniform Commercial Code Law Journal 63, 64: '[P] rovincial PPS choice of law rules are almost identical to each other. ... comments [in this article] with respect to the OPPSA choice of law provisions will generally be applicable to the PPS laws across Canada.'

17 See, e.g., European Bank for Reconstruction and Development, Model Law on Secured Transactions (2004), available at http://www.ebrd.com/news/publications/guides/model-lawon-secured-transactions.html; Organization of American States, Model Inter-American Law on Secured Transactions, available at https://www.oas.org/dil/Model_Law_on_Secured Transactions.pdf. In this connection the enormously successful Cape Town Convention (CTC) and its Aircraft Protocol (AP) also should be mentioned, although they involve an object-based registry rather than an assignor identifier-based registry, as contemplated by the Modern Principles. See Convention on International Interests in Mobile Equipment 2001, 2307 UNTS 285 (CTC); Protocol to the Convention on International Interests in Mobile Equipment on Matters Specific to Aircraft Equipment 2001, 2367 UNTS 517. Since entering into force on 1 March 2006, the CTC and AP have been adopted by 73 contracting States and one regional economic integration organization (European Union). UNIDROIT, 'Status of the Convention on International Interests in Mobile Equipment' <http://www.unidroit.org/status-2001capetown> accessed 1 July 2017.

18 E.g., Colombia, Ley No.1676 del 20 de Agosto de 2014 'Por la Cual se Promueve el Acceso al Crédito y se Dictan Normas sobre Garantías Mobiliarias'; See Mayer Brown, 'Colombia’s New Law on Security Interest over Movable Assets Comes into Effect (28 April 2014) available at https:// www.mayerbrown.com/files/Publication/4868229b-de56-4b53-8669-a55fcfdd728a/Presentation/ PublicationAttachment/56e374b9-fab3-467f-b3b1-aa1d67beafbb/Update_New_Regulations_ Moveable_Assets_Colombia_0414.pdf.

19 These states currently include, e.g., Chile, Jordan, Paraguay, Sri Lanka, and St. Lucia. E-Mail from Andres F Martinez, Senior Financial Sector Specialist, World Bank Group, to Charles W Mooney Jr, Professor, University of Pennsylvania Law School (1 July 2017, 08:34 EDT) (on file with author); E-Mail from Murat Sultanov, Secured Transactions Specialist, World Bank Group, to Charles W Mooney Jr, Professor, University of Pennsylvania Law School (1 July 2017, 07:41 EDT) (on file with author). 
exist, and debates continue as to a host of specific and recurring issues in secured transactions law. But there is little doubt that there has emerged a global consensus as to a set of general principles to which secured transactions law should adhere, although for any given State the political realities may inhibit full implementation of these principles, and disagreements on details necessarily persist.

Of course, no listing of Modern Principles would (or could) provide an ideal or perfect taxonomy, free from all error, controversy, and debate. Under any plausible catalogue of principles, differing views also no doubt exist as to the optimal level of detail in articulating them and as to the relative significance of the individual principles. That said, for present purposes, I would propose the following as the Modern Principles:

(i) public notice as a general condition for third-party effectiveness (perfection), including:

(x) establishment of an assignor identifier-based security rights registry for registration of notices of security rights (a so-called 'notice-filing' system), thereby enhancing transparency and supporting and legitimizing effective nonpossessory security rights, and

(y) continued recognition of the historical effectiveness of possession of tangible assets for this purpose;

(ii) provision of clear and predictable priority rules to enhance certainty;

(iii) facilitation of the enforcement of security rights following a debtor-assignor's default.

(iv) making available as encumbered assets all types of personal property, including future assets, securing future obligations;

(v) free assignability of receivables;

(vi) comprehensive coverage of all forms of security devices;

(vii) the general extension of security rights to the proceeds of encumbered assets (i.e., to what is received on the exchange of or collection of encumbered assets); and

(viii) the general acceptance of freedom of contract for relations between assignors and assignees.

This listing presents the Modern Principles in roughly their order of importance or significance to the operation of an effective secured transactions regime. The analyses of stakeholder interests presented in this section and the assessments of STCOL rules in section III proceed in this order. (But one need not be overly concerned with this order of significance, as substantial incorporation of each of the principles is essential). Principles (i) and (ii) reflect the importance of balancing the interests of assignees with the interests of third parties, such as an assignor's creditors and buyers of encumbered assets from assignors. Principle (iii) recognizes the crucial role of the enforcement of a security right as the means of recovering value from the encumbered assets. Principles (iv), (v), and (vi) reflect the significance of a broad and expansive scope of a security rights. And Principle 
(vii) acknowledges the need for flexibility in the contractual relations of parties to secured transactions, as is the case for commercial transactions more generally.

The overarching thesis of this article is that the STCOL rules should serve the substance and goals of the Modern Principles. ${ }^{20}$ But that is not to say that the STCOL rules are somehow of a status that is inferior to the relevant substantive legal doctrine. Indeed, because contemporary secured transactions traverse borders, involve transactions among market participants of many nationalities and locations, and cover assets with connections to multiple jurisdictions, the STCOL rules are an indispensible and core component of secured transactions law. Because the STCOL rules should serve and support the other Modern Principles, however, they are sui generis. ${ }^{21}$ When necessary for this support, the rules must enthusiastically diverge from traditional doctrines of private international law. Both substantive secured transactions law and the STCOL rules should serve the needs of the market participants and facilitate secured transactions. It follows that those who bring knowledge and experience with secured transactions, including the relevant legal doctrine and transactional contexts, have the most to offer in the discourse on STCOL rules. But development of the STCOL rules also must build on and accept guidance from the rich scholarship and traditions of private international law. Thus, it also follows that secured transactions mavens who appreciate the goals—and central role—of the STCOL rules have the most to contribute to the dialogue.

Following this introduction, section II of the article addresses the interests of the principal stakeholders affected by the STCOL rules. It identifies the assumptions that underlie the identification and analysis of stakeholder interests, including the simplifying assumption of widespread adoption of the Modern Principles. II also addresses and explains the potential value of harmonized STCOL rules even in the absence of the general acceptance of the Modern Principles. It then identifies the relevant stakeholders affected by STCOL rules and their respective interests.

Section III then assesses various potential STCOL rules for each major type of encumbered asset by examining these rules for each component of secured transactions law—-perfection, priority, creation, enforcement against the assignor, and, for TPO encumbered assets, enforcement against obligors. Consistent with the article's thesis, the principal normative standards for assessing STCOL rules are the extent to which those rules would further the Modern Principles and balance the interests of stakeholders. Along the way, section III also considers the STCOL rules under the Model Law and North American law by applying the interest-of-

20 This reflects what Symeon Symeonides has called 'result-selective statutory choice of law rules'. Symeon C Symeonides Codifying Choice of Law around the World (Oxford University Press 2014) 251 (Symeonides, Codifying): Result-selective rules ... are specifically designed to accomplish a certain substantive result that is considered a priori desirable. More often than not, this result is favored by the domestic law of not only the enacting state, but also the majority of states that partake in the same legal tradition. Ibid.

21 Given this context, for convenience the references here to the Modern Principles generally are to their substantive components. But the STCOL rules nonetheless are a crucial to the Modern Principles. 
stakeholders-based and Modern Principles-based framework advocated here. Indeed, these rules provide a concrete setting for the application and testing of the analytical framework proposed here. Section IV then concludes the article.

\section{Stakeholder interests}

\section{Assumptions underlying analysis of stakeholder interests}

This article approaches the content of STCOL rules from the general perspective of the impact that rules would have on the various stakeholders-parties to transactions and affected States. This approach is particularly apt inasmuch the Modern Principles incorporate substantive rules that reflect a balance of the interests of the various stakeholders. ${ }^{22}$ The analysis entails consideration of the potential effects on stakeholders of any particular STCOL rule. However, without the aid of simplifying assumptions, the identification and assessment of such effects would be impractical, if not impossible. This is because any stakeholder's views on a particular rule will be (at least) a function of, inter alia, (i) the substantive rule that most favours that stakeholder's situation in a particular case (or in typical cases for that stakeholder); (ii) the STCOL rule that would point to the law of a State that has adopted that substantive rule; and (iii) the case being before (or assumed in the future to be before) a forum in a State that has adopted that STCOL rule.

Consider an example. Assume (as I will claim below) that the optimal STCOL rule for perfection of a security right in a receivable would point to the law of the State of an assignor's location (for example, its principal place of business or domicile). Assume further that State A's substantive law on secured transactions is poor (including few if any of the Modern Principles), and State A's political climate makes reforms in the near to medium term unlikely. Also assume that many State A-domiciled exporters have receivables governed by the laws of States with modern secured transactions laws (for example, the USA and Canada). Under these conditions, State A rationally might favour adoption (or, perhaps more likely, retention) of a STCOL rule under which the law governing a receivable (as opposed to the assumed-to-be-optimal law of the assignor's location) would apply to perfection of the assignment of a receivable. Under that STCOL rule, the State A exporters could benefit from (presumably) lower costs afforded by the application of US and Canadian laws to perfection and priority of their assignments of US law and Canadian law-governed receivables. Even then, of course, this result would depend on the issue of perfection being (or assumed to be) before a forum that would adopt this STCOL rule (a quite plausible assumption for assignors located in State A and their assignees, assuming State A were to adopt this rule).

Given the variables, the interest-based analysis that follows assumes that the Modern Principles, including compatible STCOL rules, will be widely adopted by

22 See draft Guide, Introduction, at 3. 
a substantial number of States. This approach recognizes that in a world where many States have not adopted the Modern Principles, one cannot reliably offer any a priori conclusions about the optimal shape of the STCOL rules. Consequently, the merits of the STCOL rules will be evaluated based on this assumption of widespread adoption. This assumption, of course, underlies the normative basis of the STCOL rules that are included in the Model Law and North American laws. This is not a coincidence. These STCOL rules are quite purposefully addressed to the efficient operation of substantive secured transactions laws of which they are a part. They were designed to facilitate extensions of credit at a lower cost through secured transactions as a part of the broader codifications of the Modern Principles. ${ }^{23}$ Of course, whether these STCOL rules actually serve the Modern Principles - that is, whether these harmonized STCOL rules get it 'right' - is another question! ${ }^{24}$

The simplifying assumption of widespread adoption of the Modern Principles should not be understood to assume away the significance and role of the STCOL rules on the basis that the substantive law is the same in every State. First, adoption of the Modern Principles does not mean strict harmonization of law; differences certainly would exist notwithstanding such widespread adoption. Second, even if States were to adopt identical texts, judicial interpretations could present material disparities. Third, presumably at least some States would not adopt the Modern Principles. And, fourth, and perhaps most significant, even in an imaginary world of strict harmonization of secured transactions law, it would be necessary to specify which State's law governs the registration of notices of security rights (that is, where to register) and searches of the registry.

Even in absence of the assumed widespread substantive harmonization embracing the Modern Principles, there may be substantial value in harmonization of STCOL rules. First, such harmonization would provide certaintyboth ex ante and ex post-for market participants. Second, harmonized STCOL rules could provide incentives for States to adopt the Modern Principles. Consider the hypothetical State A mentioned above. Embracing the optimal, Modern Principle-based STCOL rule (perfection being governed by the location of the assignor of a receivable), State A might be encouraged to adopt Modern Principles so that its local assignors could reap the benefits. ${ }^{25}$ Moreover, even

23 See draft Guide, X.A.1., at 384 ('In an efficient secured transactions regime, conflict-of-laws rules applicable to secured transactions normally reflect the objectives of the secured transactions regime.').

24 In one case in particular-the Model Law's STCOL Rule for certificated non-intermediated securities-I argue below that the Model Law's rule is inconsistent with its other STCOL rules and does not gets it right. See section III.5 in this article.

25 Assuming a State's harmonized STCOL are rules directed toward supporting the Modern Principles as proposed here, such a State plausibly would also be wiling to adopt substantive secured transactions laws incorporating the Modern Principles. Even assuming such adoption, however, global developments reflect many variations on the Modern Principles, which are far from being strictly harmonized. Perhaps even more adherence to strict harmonization could be expected for the STCOL rules than with the substantive secured transactions laws. 
assuming widespread and substantial substantive harmonization, some aspects of harmonized STCOL rules would remain essential as noted above-in particular, those that govern the State where registration (and searches of the registry) are to occur. For this reason, efforts directed towards harmonized STCOL rules are welcome.

With this background, the next section identifies and considers the interests of the various stakeholders affected by STCOL rules. These interests support the framework developed here for devising optimal rules as well as for assessing existing and proposed rules. I do not claim that this discussion identifies every conceivable interest that might be implicated. But the interests identified here I believe are adequate for purposes of explaining and applying this framework.

\section{Identification of stakeholder interests}

\section{A. Third parties in general: herein of public notice and priorities}

The relevant third parties generally are the existing and future (potential) creditors of an assignor and transferees of relevant encumbered assets. For example, one considering the extension of credit to an assignor will be interested in whether assets of the assignor have been, or may be, encumbered in favour of another person (assignee). Similarly, a prospective assignee of an asset (such as a prospective buyer or secured lender of funds) from an assignor may be interested in whether the relevant asset is the subject of a security right. These stakeholders require a means of learning about existing and potential security rights in the relevant assets. They also have an interest in the nature of the applicable priority rules that would apply to a security right in the assets. For example, how would a security right rank vis-à-vis a later-in-time judgment creditor or a good faith purchaser? $^{26}$

Above all, these third-party stakeholders require an objective, easily determinable, and reliable means of determining the law applicable to the perfection and priority of security rights with respect to any relevant encumbered assets. These STCOL will determine, for example, in which State(s) a search of a secured transactions registry(ies) will be necessary or prudent. It also will determine which State's (or States') law(s) will provide the relevant priority rules. Third parties will benefit most from STCOL rules that identify the law of a single State (or, at least, the laws of fewer rather than more States) governing perfection or priority (or both). For example, an interested third party would prefer that it be

26 An interested third party will prefer that any such priority rules be 'clear and predictable,' as specified in Modern Principle (ii). But given the simplifying assumption of widespread adoption of the Modern Principles, this section of the essay focuses more narrowly on the interests of the various stakeholders with respect to the STCOL rules, not more generally on the Modern Principles. 
required to search the registry or consult the laws of a single State rather than multiple States, thus lowering its transactions costs and reducing delay. ${ }^{27}$

\section{B. Assignees}

The interests of assignees (and prospective assignees ${ }^{28}$ ) mirror in many respects those of third parties in general, which was just discussed. An assignee, like third parties generally, will be interested in the law applicable to perfection and priority, for essentially the same reasons. Likewise, an assignee will prefer that a single State's laws, or at least the laws of fewer rather than more States govern perfection and priority, thus reducing costs and saving time and effort. Limiting the potential number of States' laws that would apply to perfection and priority also will more efficiently accommodate transactions involving encumbered assets that have connections to many States. An actual assignee also must rely on the applicable law to ensure that it is taking the necessary steps under that law for achieving perfection (such as registration in the security rights registry or taking possession of encumbered assets) and priority of its security right.

The assignee's perfection of its security right necessarily will involve as well the steps necessary for the creation of the security right under the applicable law, so as to be effective as between the assignor and assignee. An essential component of the creation will be the existence of the assignor's rights in the encumbered assets or its power to transfer rights. The assignee also will need to ensure that its contractual relationship with the assignor is enforceable under the applicable law. Moreover, with respect to TPO assets, the assignee need concern itself with two other matters under the applicable law. First, it must be satisfied as to the enforceability under the applicable law of the third-party obligor's obligation to the assignor that underlies the TPO asset (for example, the obligation of a third-party obligor to pay a receivable). Second, the assignee must consider its own right, as assignee, to enforce that obligation against the third-party obligor under the applicable law.

\section{Assignors}

The most pressing and practical interest of an assignor typically is the satisfaction of the conditions necessary for obtaining secured credit from the assignee or otherwise transferring the encumbered assets to a transferee for value. In that sense, the assignor's interests are precisely coextensive with those of the assignee, and the STCOL rules that best accommodate the assignee interests will likewise accommodate the assignor. Of course, as to matters for which under the

27 An international or regional registry could provide similar benefits. See Charles W. Mooney, Jr., 'The Cape Town Convention's Improbable-but-Possible Progeny Part One: An International Secured Transactions Registry of General Application' (2014) 55 Virginia Journal of International Law 163. But the operation of such a registry would require the adoption of an STCOL rule that would point to its applicability.

28 While not all prospective assignees will ultimately receive an assignment, all actual assignees were once prospective assignees. For this reason references here to the interests of assignees as stakeholders also include prospective assignees. 
applicable law the assignor and assignee are afforded party autonomy, each party may prefer the law of a different State. For example, each may prefer its 'own' 'local' law when the parties are located in different States. Or a party may prefer the law of a State that it believes may be more accommodating to its own interests (for example, a State perceived to be more 'debtor-oriented' or 'creditororiented').

\section{Third-party obligors on TPO assets}

Consider next a third-party obligor on a TPO asset. The third-party obligor has become bound to a prospective assignor on a receivable or negotiable instrument, has issued a negotiable document or security to a prospective assignor, or has credited a securities account for the benefit of its prospective assignor-account holder. Although the third-party obligor's obligations have become choate under the relevant contractual (or other) arrangement and the applicable law, the obligations at that point remain unaffected by the application of the STCOL rules. Once the assignor assigns the TPO asset to an assignee, however, one must consider any impact that the application of STCOL rules may have on the third-party obligor's obligations. As to some of the STCOL rules, the third-party obligor has important interests and concerns to be considered; as to others, the third-party obligor typically will be indifferent and unaffected.

One significant potential interest of a third-party obligor on a receivable, for example, is the issue of whether it is assignable at all. ${ }^{29}$ This often turns on whether there are contractual or legal restrictions on the assignment that are effective under the applicable law. The simplifying assumption made here has swept this issue aside, however, inasmuch as one of the Modern Principles assumed to be widely adopted is the 'free assignability of receivables'. But important additional concerns of obligors remain nonetheless. Of paramount importance to the obligor on a receivable, for example, is certainty as to whom to pay (and how to pay, where to pay, and so on) in order to discharge and satisfy its obligation. ${ }^{30}$ If, and to the extent that after an assignment the obligor will become obligated to pay and perform to and for the benefit of the assignee, the obligor requires certainty as to its obligations. In contrast, the obligor normally will have little, if any, interest in the identity or status of the 'ultimate' beneficiary of its payment and performance. For example, the priority among competing claims of multiple assignees or the effectiveness (perfection) of the assignment(s) as against other third parties or the assignor's insolvency representative will be of little consequence to the obligor. The appropriate STCOL rule in this context must

This discussion of receivables also is relevant for third-party obligors on other TPO assets, such as bank accounts and securities accounts. On the other hand, the raison d'être for issuing certain other common types of TPO assets, namely negotiable instruments and documents of title, is the ready transferability of those items of commercial specialty. Thus, assignability is inherent and assumed.

30 This certainty as to payment or other means of performance of obligations is likewise important to third-party obligors on other types of TPO assets. For convenience this discussion refers to receivables and to performance by payment. 
take account of the obligor's interests (or lack thereof) in balancing these interests against those of the other stakeholders.

\section{E. States}

It is generally accepted that States have an interest in the shape and application of choice-of-law rules that determine outcomes among private parties. ${ }^{31}$ But the State interests implicated by the STCOL rules contemplated here would not favour 'competition' among States, each seeking to achieve advantages over the competing interests of other States. Given the simplifying assumption made here, States would have a paramount interest in adopting STCOL rules that serve the Modern Principles (as well as adopting the Modern Principles, of course). Stated otherwise, States would have an interest in serving multi-State interests of the international community flowing from a common acceptance of the Modern Principles. ${ }^{32}$

Some more-or-less self-serving State interests, of course, will not necessarily be at odds with the multi-State acceptance of the Modern Principles. In fashioning and adopting the STCOL rules, States may appropriately take into account such self-serving interests in balancing the various stakeholders' interests. For example, in the context of property law, in general, and secured transactions, in particular, a State has legitimate concerns with regulating transactions in property that is physically situated within its borders. ${ }^{33}$ A State also has an interest in adopting priority rules that promote efficiency, fairness, and predictability and that are supportive of markets operating within the State. These concerns are related in part to a State's interest in protecting the rights of its citizens and residents and those who transact business within the State. States also properly take steps to ensure that their local laws are properly enforced and interpreted and not unnecessarily limited in scope, including any extraterritorial scope. All of these interests may in many situations be accommodated without impairing the mission or operation of STCOL rules that support the Modern Principles. Indeed, the Modern Principles in many respects address these State interests (for example, by including clear and predictable priority rules).

Some self-serving State interests may, on the other hand, conflict with the Modern Principles. For example, a State might pursue a 'forum-shopping' agenda of seeking to attract business for its registry, thus generating fee revenues.

31 For example, as Symeon Symeonides has observed with respect to the Restatement Second's 'most significant relationship' principle: 'The state with the most significant relationship is not to be chosen by the quantity or even the closeness of its factual contacts, but rather 'under the principles stated in $\$ 6$,' which include consideration of the policies and interests of the contact-states'. Symeon C Symeonides Choice of Law (Oxford University Press 2016) 113.

32 Note that the relevant role of States for these purposes is the process of codifying STCOL Rules-not balancing of competing State interests by a forum court seeking to determine the appropriate applicable law to a given matter in dispute.

33 See, e.g., UCC 9-301, comment 7 (1st and 2nd paras) (location-of-asset STCOL priority rule for tangible assets avoids problems that would result from location-of-assignor rule governing priority of judicial lien on goods located in another jurisdiction). 
To this end, it might manipulate its STCOL rules in a manner that could impair, rather than serve, the Modern principles.

\section{Balancing the stakeholder interests}

Having identified the principal stakeholder interests implicated by the STCOL rules, section III next offers a framework for assessing these rules (both existing rules and those that might be considered for adoption in the future) based on the Modern Principles and a balancing of stakeholder interests. It applies the framework to the most important and controversial STCOL rules through an issue-byissue and asset type-by-asset type consideration. By this means, the assessment seeks to balance the various stakeholder interests in the contexts of each of the principal components of secured transactions law embodied in the Modern Principles-perfection, priority, creation, and enforcement (as against an assignor and as against a third-party obligor). As will become apparent (and as is well known to many readers), the STCOL rule that is appropriate for the issue of perfection, for example, may not be appropriate for purposes of priority. And the appropriate STCOL rule for perfection by registration may not be appropriate for perfection by taking possession. In similar fashion, the optimal rule for a particular issue involving one type of asset is not necessarily the appropriate rule for another type of asset. The codification process thus involves a form of 'legislative or statutory dépeçage ${ }^{34}$ Moreover, application of the analytical framework suggested here necessarily entails making some factual assumptions about the characteristics of the secured transactions, and their components, to which any given STCOL rule would be applied. The analysis in section III proceeds accordingly.

\section{The framework for an interest-based and modern principles-based assessment}

This section takes up first the STCOL rules for third-party rights and issuesnamely, perfection and priority. ${ }^{35}$ Note that the first two of the Modern Principles

34 See Symeonides, Codifying (n 20) 224. Symeonides is referring to multiple aspects of a cause of action, however, as opposed to the components of a secured transaction as contemplated here.

35 As explained above the appropriate STCOL for perfection may differ from that applicable to priority, depending on the type of asset and method of perfection. For this reason the following discussion addresses perfection and priority separately. One should note, however, that perfection-third-party effectiveness-necessarily embodies the concept of priority inasmuch as the essence of a perfected security right implies priority over general creditors (including judgment creditors). Note also that this essay does not take up in any detail certain 'special' perfection and priority STCOL rules, such as for goods normally used in more than one jurisdiction, goods in transit from one State to another State, bank accounts, intellectual property, securities (but see the treatment of non-intermediated securities in section III.5 below), etc. It also does not address the temporal components of STCOL rules. See, e.g., Model Law art 88(1) (location of asset at time enforcement is commenced); 91 (time for determination of location of asset or assignor). Moreover, it does not deal with the treatment of changes in factors that determine the applicable law. See, e.g., Model Law art 91(2) (change in location of asset or assignor). All of these aspects of STCOL rules would benefit from the application of the interest-based and Modern Principles-based framework for assessment proposed here. 
address these attributes of secured transactions law. Although the listing of the Modern Principles presented here may not reflect precisely their order of importance, most would agree that the third-party issues addressed by perfection and priority rules represent the signature, touchstone issues for secured transactions law-and, consequently, for the STCOL rules.

\section{Perfection}

\section{A. Perfection by registration}

\section{(i) Intangible assets (herein of receivables and other intangibles)}

For perfection by registration of a security right in receivables, ${ }^{36}$ the interests of third parties in general (essentially as searchers) as well as assignees and assignors (as actual parties to a secured transaction and registration of a notice) would be served best by the general applicability of the law of a single State that is easily and objectively determinable. ${ }^{37}$ But the determination of which (single) State's law ought to govern requires some factual assumptions about these secured transactions. For example, on the assumption that the paradigmatic transaction involves numerous receivables (a so-called 'bulk' assignment) that are connected to many States, an asset-centric (that is, receivables-oriented) STCOL rule based on connections between the receivables and those States likely would not satisfy the needs of these stakeholders. Such a rule might contemplate searches and registrations in a multiplicity of States for a single transaction with a single assignor. Instead, an assignor-centric rule based on objectively determinable characteristics of the assignor would be more appropriate. ${ }^{38}$ This is, of course, the general STCOL rule that the Model Law and North American law provide-perfection

36 As used here 'receivable(s)' refers generally to rights to payment that are not evidenced by a negotiable instrument, such as a promissory note. Typical rights to payment that are the subject of commercial financing transactions include those arising out of the sale of goods or services, but the term is not so limited as used here. See, e.g., Model Law art 2(dd) (defining 'receivable'); UCC 9-102(a)(2) (defining 'account'), (11) defining 'chattel paper'), (61) (defining 'payment intangible').

37 For discussions of the STCOL rules for assignments of intangibles see the presentations (2017 Colloquium Presentations) prepared for a panel on the Law Applicable to the Proprietary Effects of Assignments of Receivables, at the Fourth International Colloquium on Secured Transactions, 15-17 March 2017, Vienna, http://www.uncitral.org/uncitral/en/commission/colloquia/4thint. html: Maria Vilar Badia, 'The Law Applicable to Third-Party Effects of Transactions in Claims and Securities in EU Law'; Yuko Nishitani, 'Cross-Border Assignments of Receivables: Conflict of Laws in Secured Transactions'; Christian Heinze, 'The Law Applicable to Proprietary Effects of Assignment of Receivables and Insolvency'; Eva Lein, 'BIICL Study Assignment and the Rome I Regulation: Effectiveness of an Assignment of a Claim against Third Parties and Priority of the Assigned Claim'; Catherine Walsh, 'The Law Applicable to the Proprietary Effects of Assignments of Receivables: Introduction'; Peter Winship, 'The Law Applicable to Proprietary Effects of Assignments of Receivables'.

38 An assignee-centric rule also could address the problem of a multiplicity of governing laws, assuming a single assignee, but interested third parties would have no way of objectively ascertaining the identity, and thus the characteristics, of the assignee (or all conceivable assignees). 
of a security right in receivables (and intangibles generally) is governed by the law of the location of the assignor. ${ }^{39}$

Given this assumed paradigm, the more 'traditional' asset-centric rule that would apply the law governing the receivable (the assignor's claim against the obligor) to govern proprietary rights arising out of the assignment would be inappropriate. That law-governing-claim STCOL rule would invite precisely the multiple searches and registrations in multiple States that third parties, assignors, and assignees alike would most wish to avoid. Moreover, this would require legal due diligence as to each such State, and some of those States may not have registration-based perfection and priority rules. ${ }^{40}$ Unfortunately, this lawgoverning-claim STCOL rule persists in several jurisdictions. ${ }^{41}$ Moreover, that traditional asset-centric rule could not accommodate with any certainty the coverage of future receivables because it would be impossible to determine the law governing a claim that does not yet exist. ${ }^{42}$ Of course, these difficulties of dealing with multiple States and registries would be substantially eliminated if the law governing all of the assigned receivables happened to be the law of the same State. For example, a multinational firm might have sufficient bargaining power to ensure that its preferred applicable law governed all (or almost all) of its

39 Model Law art 86; UCC 9-301(1); OPPSA 7(1) (law of jurisdiction of location of debtor governs perfection and priority for intangible assets, mobile goods, and negotiable assets). It also is the STCOL rule under the United Nations Convention on the Assignment of Receivables in International Trade 2001 (New York) http://www.uncitral.org/pdf/english/texts/payments/receivables/ctc-assignment-convention-e.pdf (Receivables Convention). Receivables Convention arts 22, 30(1). Under the Receivables Convention perfection is subsumed for this purpose under the concept of priority. Receivables Convention art 5(g) (defining 'priority'). For a thorough analysis supporting adoption of the location-of-assignor STCOL rule, with appropriate exceptions, see Harry C Sigman and Eva-Maria Kieninger, eds, Cross-Border Security over Receivables (2009) 46-73. More recently, Catherine Walsh has provided an utterly convincing analysis and argument supporting the location-of-assignor STCOL rule. Catherine Walsh, 'The Law Applicable to the third-Party Property Effects and Priority of an Assignment: Whither the EU?' (2017) [cite this issue] (Walsh, 'Assignment'). Notwithstanding the simplicity of such a 'one-size-fits-all' location-of assignor STCOL rule, one can imagine real-world examples to which a law-governing-claim rule would be more convenient for assignees. For example, if the same receivable is assigned multiple times (assignee 1 to assignee 2 to assignee 3 , etc.), with each assignee located in a different state, this would require each successive assignee to search in its assignor's location and in the locations of earlier assignors in the chain. No single STCOL rule would best accommodate the interests of every assignee in all scenarios.

40 This could negate the economic viability of many multistate assignment transactions.

41 See, e.g., Christian Heinze and Cara Janine Warmuth*, 'The Law Applicable to Proprietary Effects of Assignment and Its Interplay with Insolvency' (2017) (Heinze, 'Law Applicable') [this issue]; Yuko Nishitani, 'Cross-Border Assignment of Receivables-Conflict of Laws in Secured Transactions' (2017) (Nishitani, 'Cross-Border') [this issue]; Walsh, 'Assignment' (n 39) xr.]

42 A thorough analysis of this ill-advised rule is beyond the scope of this essay. For additional analysis and critique, see Heinze, 'Law Applicable' (n 41); Nishitani, 'Cross-Border (n 41); Walsh, 'Assignment' (n 39); see also 2017 Colloquium Presentations (n 37). But it is worth noting the weakness of one justification for an asset-centric law-governing-claim rule that sometimes is offered in its support. It is argued that the assignee must examine the law governing an assigned receivable in any event in order to determine, inter alia, the validity of the assignor's claim against, and the corresponding obligation of, the third-party obligor. But such a straightforward examination (in lieu of which assignees in bulk assignments normally rely on representations of the assignor) would not entail an examination of the relevant State's secured transactions regime, including its rules on perfection (registration) and priority. Moreover, that purported justification does not come to grips with the potential burdens of searching and registration in multiple jurisdictions. 
receivables. ${ }^{43}$ And its preferred applicable law might well be the law of the State of its location. Under that scenario, the same law would apply to perfection by registration under either of the posited STCOL rules. Conversely, however, it is also plausible that the obligors on an assignor's receivables would have the superior bargaining power. This could lead to each receivable being governed by the law preferred by the obligor of the receivable, once again resulting in a multiplicity of governing laws (and States in which searches and registrations would be necessary).

Now adjust the assumed paradigmatic transaction. Assume it to be the assignment of a single receivable (such as a payment stream under a lease of an expensive item of equipment) by a 'special purpose entity' that was created for the sole purpose of acquiring and leasing the equipment to the obligor (lessee). Under this paradigm, the assignee and assignor would be agnostic as to whether a law-governing-claim (that is, the law governing the receivable, the lease) STCOL rule or a location-of-assignor rule were the law governing perfection by registration-in either case, the law of a single State that is readily determinable (by them) would apply. But third parties that might have an interest in the assignor's affairs (that is, whether it has assigned any of its assets), would have no reliable and objective means of discovering the existence of this (or any other) receivable-much less its governing law under a law-governing-claim STCOL rule. In the real world, it must be the case that both of the assumed paradigmatic transactions patterns giving rise to receivables actually occur as well as the more probable situationassignors with many receivables that fall in between these polar examples. An appropriate STCOL rule should accommodate the entire range of receivablesgenerating transactions.

Consider next the situation of the interests of third parties, assignors, and assignees, that are 'small,' 'local,' presumably unsophisticated parties. Under the assignor-centric location-of-assignor STCOL rule, an interested third party or assignee may be required to search and register notices in the registry of a foreign State of an assignor's location - that is, a State other than the 'home' State of the searching or registering party (that is, the State of that party's place of business or domicile). Arguably, this could impose a hardship on the local party. Given the assumed widespread adoption of the Modern Principles, however, one might hope that such foreign registries would be accessible and user friendly for the local party, thus mitigating any such hardship. Moreover, under an asset-centric rule such as the law-governing-claim STCOL rule, such local parties might be required to deal with multiple foreign registries. This situation might be even more burdensome than searching and registering under a location-of-assignor rule. On the other hand, it is also plausible that the local parties generally are

43 Even with such bargaining power it is likely that for many assignors a nontrivial number of its receivables would be governed by the law preferred (and designated) by third-party obligors on receivables through the operation of the so-called 'battle of the forms'. See, e.g., Giesela Ruhl, 'The Battle of the Forms: Comparative and Economic Observations' (2003) 24 University of Pennsylvania Journal of International Economic Law 189. 
interested in, and deal with, primarily local assignors (located in the same home State) and that the local assignors' receivables typically are governed by the law of that same home State. Under those hypotheses, the same law would apply under either of the posited STCOL rules, and such local parties would not experience material adverse effects from application of the assignor-centric location-ofassignor STCOL rule. This analysis suggests that, on balance even in a State where such local interests dominate the location-of-assignor STCOL rule might well be in the best interests of third parties, assignors, and assignees. ${ }^{44}$

What of the interests of the other stakeholders - the obligors on the receivables and potentially interested States? Assuming satisfactory STCOL rules and substantive rules that provide adequate assurance to the third-party obligors as to whom they should pay (render performance) to satisfy their obligations, ${ }^{45}$ the obligors would be indifferent as to the law governing perfection of the assignment by registration. Given this, the same conclusion would apply to the States whose laws might govern the receivables or which might be the domiciles of the obligors. An asset-centric law-governing-claim STCOL rule might have superficial appeal to a State whose law would govern. But the State's actual interest would be aligned with those of its domiciliary obligors - interests that are real and important, but which would not extend to the issue of perfection by registration addressed here. The assignor-centric location-of-the-assignor STCOL rule thus meets the needs of third parties and assignors and assignees irrespective of the assumptions as to paradigmatic receivables transactions. But that rule would not impair the interests of the third-party obligors or interested States. ${ }^{46}$

Finally, possibly the most compelling argument in support of a location-ofassignor STCOL rule for perfection by registration for receivables is the direct connection between the method of perfection-registration-and an assignorcentric location-of-assignor STCOL rule. The Modern Principles contemplate a security rights registry based on an assignor (grantor) identifier, such as the assignor's name. ${ }^{47}$ Given such a registry, searchers would search according to the

44 In the case of an insolvency proceeding of the assignor it also is likely that the location of the assignor would be the State in which a main proceeding would be commenced and administered. See, e.g., draft Guide, X.A.5.(a), at 393; UNCITRAL Model Law on Cross-Border Insolvency (1997) http://www.uncitral.org/pdf/english/texts/insolven/1997-Model-Law-Insol-2013-GuideEnactment-e.pdf, art 2(b) (defining 'foreign main proceeding; 16(3) (presumption that debtor's registered office is its center of main interests.

45 See section III.4.B in this article (discussing, inter alia, law governing rights and obligations of third-party obligors).

46 A State might adopt self-serving STCOL rules that impair the Modern Principles. For example it might opt for a rule that it perceives would attract registrations for its registry. And an asset-centric law-governing-claim rule might be the most easily manipulated one for facilitating such 'forum shopping' (i.e., it would be easier for parties to a receivable to choose a particular governing law than for an assignor to change its location to accommodate an assignor-centric locationof-assignor STCOL rule). But it is unclear why such a State would prefer the asset-centric to the assignor-centric rule. Assuming (as argued here) that the latter rule provides greater benefits to third parties and assignees (and therefor assignors) in terms of reduced searching and registration costs and burdens, a State's adoption of the former rule could discourage assignors from choosing that State's laws to govern receivables.

47 Draft Guide, recs 54(c), 58, at 179-80. 
assignor's identifier, and assignees would register against, and registrations would be indexed according to, that identifier. To participate in this system, an interested person necessarily must know an assignor's identifier. Under a location-ofassignor STCOL rule, it would be the identity of the assignor (as opposed to, for example, characteristics of any particular assets of the assignor) that would determine the State in which to search and register for assignments made by that assignor. ${ }^{48}$

Beyond receivables, what would be the optimal STCOL rule for perfection by registration of security rights in other (non-reified) intangibles such as bank accounts, securities accounts, uncertificated securities, tort claims, rights under various contractual arrangements such as franchise agreements, and intellectual property (to the extent not covered by specialized statutes)? Would, for example, issues involving 'bulk' assignments be less significant for many of these types of assets than in the case of assignments of receivables? Some of these assets, such as bank accounts, uncertificated securities, and securities accounts, are subject to perfection methods other than registration under the Model Law and North American law. ${ }^{49}$ In general, an examination of the various financing patterns and commercial settings involving these various types of assets is beyond the scope of this article. Nonetheless, the factors militating towards a location-ofassignor STCOL rule for perfection for receivables would appear to be applicable as well for perfection by registration for these other types of intangibles.

Summing up this discussion, first, the assignor-centric location-of-assignor STCOL rule for perfection by registration of a security right in intangibles (receivables, in particular) appears to satisfy the needs of third parties as well as assignors and assignees in all of the relevant scenarios, thus providing the least burdensome rule for accommodating searching and registration. ${ }^{50}$ Second, thirdparty obligors and States would be largely indifferent as between an assignorcentric location-of-assignor STCOL rule and an asset-centric law-governingclaim STCOL rule. Third, a location-of-assignor STCOL rule is directly connected to the core organizing principle of a security rights registry-the assignor identifier as the basis for searching and registration. Fourth, and perhaps most significant, factual assumptions about the secured transactions addressed by STCOL rules, including the relevant assets (such as receivables) are essential to any assessment of these rules. While the factual assumptions supporting these conclusions seem relatively clear and straightforward, facts are both stubborn and

48 Difficulties attendant to an assignor-identifier-based system should not be underestimated, however. A person faced with searching in a foreign state must determine and obtain access to an assignor's identifier used by that State's registration system, which may be a name or an official identification number or both.

49 Model Law arts 25 (bank accounts); 27 (uncertificated securities); UCC 9-314 (deposit accounts and investment property, including uncertificated securities and securities accounts); OPPSA 22.1 (perfection by control in investment property, including uncertificated securities and security entitlements).

50 It is worth noting that this issue is presently being considered by the European Commission and '[a] legislative proposal is expected in the fourth quarter of 2017'. See Walsh, 'Assignment' (n 39) xr; see also Badia (n 37) 7-8. 
elusive. The discussion of perfection by registration for tangible assets, considered next, further illustrates the challenges of determining the factual assumptions necessary to support appropriate STCOL rules.

\section{(ii) Tangible assets (herein of goods and negotiable assets)}

Section III.1.A.i applied the interest-based and principles-based framework proposed here to the assessment of STCOL rules for perfection by registration of security rights in intangible assets. It concluded that the assignor-centric locationof-assignor STCOL rule best served both stakeholder interests and the Modern Principles alike. This subsection applies the framework to perfection by registration for tangible assets. Perhaps the most efficient and effective analytical approach is to ask whether there is any basis for concluding that a different rule is warranted for tangible assets. The analysis here suggests that the location-ofassignor rule may be the better one for tangible assets as well as for receivables. In this respect, it parts company with the corresponding STCOL rules provided in the Model law and under the PPSAs, which opt for a location-of-asset rule for tangible assets. But this conclusion is no better than the 'best guess' factual assumptions on which it is based. Moreover, even these factual assumptions suggest that support for the location-of-assignor rule is somewhat weaker than in the case of receivables.

Consider first tangible assets consisting of goods. The foregoing interest-based analysis of perfection by registration in intangible assets identified and illuminated the fundamental question: which STCOL rule would provide the best guidance to assignees on where to search and register? ${ }^{51}$ (One is not likely to find the best answer by asking the wrong question.) An assignor's goods may be located in numerous States, just as an assignor's receivables may be governed by the laws of (or have other connections with) many States. As explained, the assignor-centric location-of-assignor STCOL rule for perfection by registration for receivables provides a single, stable, easy-to-apply, and certain rule that is most consistent with the needs of stakeholders. Keeping in mind that the context here is perfection by registration, are there good reasons why goods would warrant a different STCOL rule? ${ }^{52}$

Plausible factual assumptions concerning the circumstances surrounding assignors' goods may demonstrate that the case for a location-of-assignor rule is

51 Contrast this question with this formulation: which STCOL rule best determines 'the law applicable to the proprietary effects of assignments of receivables'-taken from the title of the 2017 UNCITRAL colloquium panel ( $\mathrm{n} \mathrm{xr}$ ). This sort of formulation may explain at least in part why the subject of 'conflict of laws' sometimes meets with enormous skepticism, as evidenced by Professor Prosser's famous prose: '[C] onflict of laws is a dismal swamp, filled with quaking quagmires, and inhabited by learned but eccentric professors who theorize about mysterious matters in a strange and incomprehensible jargon. The ordinary court, or lawyer, is quite lost when engulfed and entangled in it.' William L Prosser, 'Interstate Publication' (1953) 51 Michigan Law Review 959,971 . For myself, in this realm I must disclaim any right to the 'learned ... professor' designation, although I will defer to others as to the aptness of the 'eccentric' and 'lost' appellations.

52 For goods, the 'certainty' consideration would take into account the costs and risks associated with determining and relying on the location of goods when compared with the determination of the assignor's location. 
weaker for goods that for receivables. For example, assume that the paradigmatic situation is that most goods of an assignor are physically located in the same State as the assignor's location. This situation might be typical in particular for small, local enterprises. The location of the goods (typically, the assignor's equipment and inventory) outside of the assignor's home State, on the other hand, might be more common among assignors with truly multinational operations. But these smaller, local firms might well undertake credit sales to foreign buyers, thus generating receivables that would, at least potentially, be governed by foreign laws. If these facts were the norm, then the location-of-assignor STCOL rule would provide more benefits for receivables secured transactions than for goods secured transactions when compared to a location-of-asset rule for goods.

Stated otherwise, the burdens of searching and registering in multiple States would be a larger problem in the receivables context under a law-governing-claim rule than would be the case for goods under a location-of-asset rule. But, even if this is so-so what? The potential for multiple-State searches and registrations requirements would remain greater for goods under a location-of-asset rule than under a location-of-assignor rule. Even these assumed facts, which are more favourable to a location-of-asset rule, would not necessarily demonstrate the superiority of that rule from the perspectives of the interests of the stakeholders - third parties, assignors, and assignees. Finally, one downside of a location-of-assignor STCOL rule for perfection by registration is the bifurcation that it would create between the rule for perfection (where to search and register) and the rule for priority. As explained below, a location-of-asset STCOL rule for tangible assets is preferable for priority. ${ }^{53}$

Now consider the situation of non-professional, unsophisticated assigneesbuyers of goods that buy outside the ordinary course of business. ${ }^{54}$ (Assignees, including buyers, of receivables presumably are more typically sophisticated professionals.) These sale transactions may be assumed typically to take place in the State in which the goods being transferred are located and to involve the buyer's taking of possession of the goods. Under these assumptions, a location-of-asset STCOL rule would provide absolute clarity to a buyer as to the applicable law and, consequently, as to where to search (the local registry) for earlier notices of assignments. And, even if a location-of-assignor rule would provide equivalent clarity, these unsophisticated buyers might find it more burdensome to cope with searches of a foreign State's

53 See section III.2.B in this article.

54 It is assumed for this discussion that ordinary course buyers of goods from dealers in such goods would take free of competing claims through good faith purchase rules under the law of the State of location. Concerning the posited 'unsophisticated' buyers, Walsh has observed that 'not all third parties will have the legal acumen to appreciate that the filing venue for locally situated goods may be located in a different state.' Catherine Walsh, 'Transplanting Article 9: The Canadian PPSA Experience' (Walsh, 'Transplanting') in Louise Gullifer and Orkun Akseli (eds), Secured Transactions Law Reform: Principles, Policies and Practice (2016). One might question the likelihood that an interested person would possess the acumen necessary to appreciate the need to search (or register in) the security rights registry but would lack the acumen to determine the proper registry for searching and registration. Again, the point here is that the assumed facts may play a determinative role in assessing the appropriate STCOL rule. 
registry under a location-of-assignor rule. ${ }^{55}$ However, even taking into account this potential burden on this subset of assignees imposed by a location-of-assignor rule, one might question whether this consideration alone should outweigh the benefits of that rule to third parties and assignees more generally. ${ }^{56}$

This prospective unsophisticated buyer scenario suggests the benefit of pursuing yet additional avenues of factual inquiry: who are (or would be) the predominant users of the registries and for what purposes? In particular, which searchers and registering assignees are predominantly interested in discovering registrations made against an assignor generally and which are interested in discovering registrations affecting particular assets? Certainly, prospective buyers of goods are interested in discovering conflicting claims to the relevant goods and would fall into the latter, asset-focused class. Asset-focused searchers also would include certain prospective acquisition financers who must discover and notify earlierregistered parties in order to qualify for non-temporal priority. ${ }^{57}$ Interested thirdparty searchers, however, presumably fall into the assignor-focused class. It is plausible, and sometimes assumed, that a location-of-asset rule would favour asset-focused searchers and registering parties, and a location-of-assignor rule would favour the assignor-focused classes of registry users. ${ }^{58}$ But this is not necessarily the case. Asset-focused users are not invariably interested in assets located in a single State. For example, asset-focused users might, on balance, favour the use of a single registry under location-of-assignor rule, thus avoiding the potential for multiple searches and registrations in several States. As in other contexts, empirical evidence would be enormously helpful here, such as whether

55 To the extent that, as often might be the case, the assignors (sellers) of these second-hand goods in non-ordinary course transactions are located in the State of location of the goods, then the burden would be reduced inasmuch as the local registry would be the appropriate place to search even under a location-of-assignor rule. It also is worth noting that experience since 2001 in the United States with the location-of-assignor STCOL rule applicable to most tangible (as well as intangible) assets may be sui generis. The tasks of searching and registering in a 'foreign' State within the United States federal system may be substantially less burdensome than in the international context involving foreign States with very different legal regimes, cultures, and languages. On the other hand, to the extent that multinational enterprises typically operate through a separate subsidiary in each State, searching and registering in multiple States under either the location-of-asset rule or the location-of-assignor rule might not be problematic for third parties and assignees.

56 The prevailing facts might differ from State to State, of course. For example, market conditions might be such that the interests of the unsophisticated non-ordinary course buyers in a given State are dominant. Arguably that might outweigh the other benefits of the location-of-assignor rule, meaning an interest-based analysis would favor the location-of-asset rule in that State although the location-of-assignor rule would be more beneficial for assignees generally from a multi-State perspective. Under these circumstances, social welfare might be enhanced by the adoption of different STCOL rules by different States. On balance, however, I am skeptical about an approach that would 'slice the salami so thin' based on such finely nuanced assumptions. I remain inclined toward harmonized STCOL rules, imperfect as they might be.

57 See, e.g., Model Law art 38(2) (Option A) (acquisition security right priority); UCC 9-324(b), (c) (inventory purchase-money priority); OPPSA 33(1) (inventory purchase-money priority).

58 This is implicit in the critiques of Cuming and Walsh and of Scott. Ronald CC Cuming and Catherine Walsh, 'Revised Article 9 of the Uniform Commercial Code: Implications for the Canadian Personal Property Security Acts (2001) 16 Banking and Finance Law Review 339, 359-60 (Cuming and Walsh, 'Implications'), citing Robert E Scott, 'The Politics of Art 9' (1994) 80 Virginia Law Review 1783, 1826-9; Walsh, Transplanting (n 54) 76. 
there are material differences in preferences as between location-of asset buyers and buyers located in other jurisdictions.

Somewhat related to the prospective unsophisticated buyer scenario, the appropriateness of a location-of-assignor STCOL rule for tangible assets in the international context has been seriously questioned. ${ }^{59} \mathrm{~A}$ premise of this critique is that most of the world has adopted a location-of-asset STCOL rule for tangible property. ${ }^{60}$ But the question addressed here concerns the appropriate harmonized STCOL rule under the assumption of widespread adoption of the Modern Principles, including the relevant STCOL rules. Put differently, what rule should be included in a model law? One cannot comfortably answer this question based on the status quo. ${ }^{61}$

The draft Guide outlined a strong case for a location-of-assignor STCOL rule for tangible assets. As explained there:

Simplicity and certainty considerations could even support the adoption of the same conflict-of-laws rule (that is, the law of the grantor's location) not only for intangible assets but also for tangible assets, especially if the same law were to apply to the creation, third-party effectiveness and priority of a security right. Following this approach, one single enquiry would suffice to ascertain the extent of the security rights encumbering all the assets of a grantor. ${ }^{62}$

The draft Guide's explanation of its rejection of the location-of-assignor rule, however, is strained. It noted that ' $[\mathrm{n}]$ ot all States, however, regard the law of the location of the grantor as sufficiently connected to security rights in tangible assets. ${ }^{63}$ Whatever meaning might be imagined and attributed to 'sufficiently connected' in this context, it seems to miss the point that the issue is one of perfection by registration and the principal question presented is where to search and register in registries that are indexed based on assignor identifiers. ${ }^{64}$ Thus, the existence (or not) of any connection between an assignor's location and its tangible assets simply has nothing whatsoever to do with the issue and the question

60 Ibid at 359 ('in Canada (and most of the rest of the world), the local conflicts regime refers choice of law for perfection of interests in tangibles to the law of the situs of the collateral').

61 Cuming and Walsh recognize this. The inherent risk of foreign litigation for US perfected security interests would be eliminated if other countries were prepared to endorse the new Article 9 approach and adopt the location of the debtor as the universal choice of law rule for perfection even in the case of tangible collateral. This is unlikely to occur. Ibid. Certainly the occurrence is unlikely if that rule is rejected for a model law on the basis of such unlikelihood, as apparently was the case with the Model Law.

62 Draft Guide, X.A.3., at 388. The draft Guide went on to observe: 'There would also be no need for guidance in the event of a change in the location of encumbered assets or to distinguish between the law applicable to possessory and non-possessory rights (and to determine which prevails in a case where a possessory security right governed by the law of State A competes with a non-possessory security right in the same assets governed by the law of State B).' Ibid.

63 Ibid.

64 Draft Guide, recs 54(c), 58, at 179-80. 
presented. ${ }^{65}$ To question the 'sufficient connect[ion]' seems to question the assignor-based characteristic of the registry itself. The draft Guide explained further: 'Moreover, in many cases, adoption of the law of the grantor's location would result in one law governing a secured transaction and another law governing a transfer of ownership in the same assets. To avoid this result, States would need to adopt the grantor's-location law for all transfers of ownership.'

These comments ignore the fact that the draft Guide itself recognizes that the law of an assignor's location may govern perfection by registration of a security right in tangible assets (the issue considered here) while another State's law (location of the asset) may govern creation and priority, each involving an attribute of ownership. ${ }^{66}$ More fundamentally, 'ownership'-or the more nuanced term used in the draft Guide and Model Law, 'power to encumber ${ }^{67}$ — is a characteristic of an assignor's relationship to an encumbered asset, not an attribute of a perfected security right in that asset. Stated otherwise, a security right is created in whatever the assignor's rights happen to exist in the asset and the law governing perfection need not have any connection with those underlying rights. ${ }^{68}$ The point here is not to defend one rule or the other but, rather, to emphasize that the interest-based and Modern Principles-based analysis advocated here would focus on the principal issue affecting the stakeholders - the appropriate State for searching and registration - and not on peripheral, unrelated considerations. ${ }^{69}$

The discussion of perfection by registration in tangible assets thus far has focused on goods. Now consider tangible assets consisting of negotiable documents, negotiable instruments, and certificated non-intermediated securities (for convenience, collectively referred to here as negotiable assets). Would the interests of third parties, assignors, and assignees best be met by a STCOL rule for perfection by registration in negotiable assets which would designate the same STCOL rule as that applicable to goods (whether that be the location-of-asset rule (as provided by the Model Law) or the location-of-assignor rule)? Absent a compelling reason, it would seem inconvenient and inappropriate-and, frankly, quite odd-to require those stakeholders to search and register in one State for goods and (potentially) another for negotiable assets. But the Model Law

65 As to perfection by possession (as opposed to registration) and priority with respect to tangible assets, the connection between the location of the asset and possessory perfection and priority is enormously important. See pp 25-26 below.

66 The Model Law provides for a location-of-assignor STCOL rule for negotiable assets (negotiable documents, negotiable instruments, and certificated non-intermediated securities) if the law of the State of the assignor's location provides for perfection by registration for such assets. Model Law art 98. However, the law of the State of the location of a negotiable asset governs creation and priority of a security right. Ibid art 85 . Creation involves an attribute of ownership, the 'power to encumber' an asset, as does priority. Ibid. art 6(1) ('power to encumber' as requirement for creation); 2( $a a)$ (defining 'priority').

67 Ibid; draft Guide, rec 13, at 97-8.

68 See section III.3 in this article (discussing law governing creation of a security right).

69 The principal focus here is on the appropriate STCOL rule for registration in an assignoridentifier-based registry as contemplated by the Modern Principles. Consideration of asset-based specialized registries for tangible assets, such as those for aircraft and ships, are beyond the scope of this essay. Concerning such specialized registries, see draft Guide, III.A.5. 
contemplates the possibility of just such an odd result. Perfection by registration in negotiable assets may be governed by a location-of-assignor rule, while such perfection for goods is governed by a location-of-asset rule (as discussed above). ${ }^{70}$ However, the Model Law's rule is qualified; it imposes the location-of-assignor rule only '[i]f the law of the State in which a grantor is located recognizes' perfection by registration for such assets. ${ }^{71}$ Presumably this would be the case were an adopting State to reject the Model Law's otherwise applicable location-of-asset rule for tangible assets, at least for such negotiable assets, in favour of a locationof-assignor rule. $^{72}$

The results of applying the interest-based and Modern Principles-based framework suggested here for determining the appropriate STCOL rule for perfection by registration for tangible assets are considerably less conclusive than in the case of intangibles such as receivables. But this is no fault of the framework. This indeterminacy results at least in part from gaps in our knowledge of the applicable facts, as discussed above. (For example, who are the asset-focused searchers and who are the assignor-focused searchers? To what extent do (or would) prospective buyers be required to search in multiple States under location-of-asset STCOL rules?). In this context, further empirical investigation could be enormously worthwhile to the analysis.

Taking account of the differing interests of various subsets of the stakeholders, and the varying interests of a given set of stakeholders in different contexts, as discussed above, even with better knowledge of the facts on the ground, any harmonized one-size-fits-all STCOL rule is bound to favour some and disfavour other stakeholders. But the need for certainty as to where to search and register demands just such a rule. In sum, under this state of play, any rule will be imperfect. Given this, on balance, the case for a harmonized location-of-assignor STCOL rule for perfection by registration for tangible assets is persuasive. Regardless of the applicable STCOL rule, searches and registrations must be accomplished based on the identity of the assignor in the assignor identifier-based registries. And searches and registrations may be achieved even without any information as to the location of tangible assets. A location-of-asset STCOL rule such as that embraced by the Model Law, on the other hand, imposes the additional requirement of knowing the location of assets (which could implicate many States) and, consequently, additional potential burdens of dealing with the multiple registries. Finally, as discussed in connection with perfection by

70 See pp 19-26 above.

71 Model Law art 98.

72 One should keep in mind that many assignees of such negotiable assets may eschew any search and registration altogether by taking possession of the assets in reliance on priority afforded by the Model Law or by any innocent acquisition (good faith purchase) rules for such assets under the applicable law. Model Law arts 85 (location-of-asset rule for priority); 46(2) (good faith purchase 'takes free' rule for negotiable instruments; (49(3) (good faith purchase 'takes free' rule for negotiable documents); 51(5) (deference to other law of enacting State for non-intermediated securities). There appears to be no principled reason why the Model Law takes three different approaches (with varying and differing deference to law outside the Model Law) toward innocent acquirers of the three types of negotiable assets. 
registration for intangibles and for the same reasons, ${ }^{73}$ on balance, the interests of third-party obligors and States would not be materially impacted, much less impaired, by either an assignor-centric location-of-assignor STCOL rule or an asset-centric law-governing-claim STCOL rule.

\section{B. Perfection by possession}

Pursuant to the presumed widespread adoption of the Modern Principles, the assignee's possession would be a permissible method of perfection for tangible assets. $^{74}$ But it is highly questionable whether physical possession of tangible assets — by an assignor or assignee-provides any practical and meaningful communication to third parties generally. Certainly, the quality of any information conveyed by possession, in respect of any existing or future interests of the possessor, would not compare favourably with the information provided by a modern security rights registry. Nonetheless, possession as a method of thirdparty effectiveness essentially is a ubiquitous feature of most legal systems.

However questionable might be the practical impact of possession of tangible assets as a form of public notice, from the perspective of an assignee that in fact contemplates taking possession as a method of perfection (and the corresponding interest of an assignor), a location-of-asset STCOL provides a clear and unmistakable indication of the applicable law. An assignee in possession of the asset necessarily knows the asset's location and, consequently, the State's law that governs under such a rule. This clarity is a product of the direct connection between the method of perfection, possession, and the location of the asset. ${ }^{75}$ Thus, it is unsurprising that a location-of-asset STCOL rule is the generally accepted norm for the law governing perfection by possession for tangible assets. This is so under the Model Law and North American law, subject to limited exceptions. ${ }^{76}$

\section{By other means}

The draft Guide, the Model Law, and North American law all contemplate or provide for methods of perfection other than registration or possession and for corresponding STCOL rules and certain types of personal property assets, including bank accounts, securities accounts, and uncertificated non-intermediated securities. ${ }^{77}$ In addition, some States provide special rules for interests in other

73 See p 19 above.

74 Possession is a permissible method of perfection under the draft Guide, the Model Law, and North American law. Model Law art 18(2); UCC 9-313(a); OPPSA 22.

75 As explained above, for perfection by registration the location-of-assignor STCOL rule also reflects a direct connection between the method of perfection and the applicable law, inasmuch as secured transactions registries are based on an assignor identifier. See p 25 above.

76 Model Law art 85(1); UCC 9-301(2); OPPSA 5(1). There is no apparent reason why the interests of third-party obligors or States would support a different approach in this context. As discussed below, the Model Law makes a notable exception for certificated non-intermediated securities. See III.E. in this article.

77 See n 49. 
types of personal property assets, such as intellectual property. ${ }^{78}$ An assessment of these STCOL rules is generally beyond the scope of this article. However, some of the relevant considerations are addressed below in connection with the Model Law's STCOL rules for certificated non-intermediated securities. ${ }^{79}$

\section{Priority}

Much of the discussion of the STCOL rules for perfection applies as well to the rules for priority. However, the STCOL rules for priority contests may implicate special considerations that in some cases support the STCOL rules that differ from those applicable to perfection. ${ }^{80}$

\section{A. Intangible assets}

The Modern Principles instruct that registration in the security rights registry is the principal method of perfection for security rights in receivables and other intangible assets. As explained below, the interests of third parties, assignors, and assignees dictate that the STCOL rule applicable to perfection for intangibles should apply as well to issues of priority. Moreover, the application of the same State's law to both perfection by registration and priority for intangibles is appropriate irrespective of the STCOL rule (location-of-assignor, law-governing-claim, or any other rule) chosen for perfection by registration. ${ }^{81}$ The crucial point is that the same State's law should apply to both perfection and priority.

Adopting the same STCOL rules for perfection and priority in this context recognizes that under the Modern Principles registration in inextricably connected to priority-in particular, the generally applicable first-to-register priority rule. ${ }^{82}$ It is that State's registry that determines priority as well as perfection. It follows that application of one State's law to perfection by registration in that State's registry and another State's law to priority would make little sense. ${ }^{83}$ The reasons that would support the selection of a State's law to apply to perfection by registration for intangibles (and, consequently, as the appropriate State's registry for searches) would apply equally to the selection of that State's law for priority.

See draft Guide, III.1.E (discussing specialized registries).

See section III.5 in this article.

${ }^{80}$ As a reminder, perfection as used here means the effectiveness of a security right as against an assignor's general creditors, including judgment creditors, and insolvency representative, which is itself a particularized priority contest. See xr below.

81 See the next following paragraph below.

82 See Model Law art 29; UCC 9-322(a); OPPSA 30(1). Even when the first-to-register priority rule does not apply, the registry may play a crucial role for purposes of priority. For example, an acquisition security right priority may require advance notification to assignee's whose interests have been registered. See $n 57$ Note also that the STCOL rules for priority under North American law refer also to 'the effect of perfection or non-perfection', which is, essentially, priority. See, e.g., UCC 9-301(1); OPPSA 5(1). Curiously, for tangible assets OPPSA section 5(1) refers only to 'the effect of perfection or non-perfection' and not to 'priority', while OPPSA section 7(1) refers to both terms. For convenience, this article refers only to 'priority'.

83 Even accepting the simplified assumption of widespread adoption of the Modern Principles, the relevant STCOL rule should avoid even the possibility that a rule would point to the law of a State that does not recognize registration as a method of perfection. 
There is no apparent reason why the same States' law should not apply to perfection and priority alike. This is the situation under the STCOL rules proposed in the draft Guide and provided in the Model Law and North American law. ${ }^{84}$

Consider next the interests of the States whose laws apply to registration in those States' registries. Those interests also would be served by adopting the same applicable law for priority - otherwise the role of those States' registries would be diminished or rendered superfluous. On the other hand, the relative indifference of third-party obligors to the law applicable to perfection would also extend to the law applicable to priority.

\section{B. Tangible assets}

As just explained, it is appropriate for the same State's law to apply both to perfection of a security right in intangible assets by registration and also to priority of the security right. For tangible assets, however, under the Modern Principles perfection may be achieved not only by registration but also by possession. There are good reasons why a location-of-asset STCOL rule should apply to priority for tangible assets even if a location-of-assignor rule applies (as suggested here ${ }^{85}$ ) to perfection by registration. Specifically, for the same reasons that the location-of-asset STCOL rule should apply to perfection by possession of tangible assets (also as advocated here), that rule also should apply to priority for tangible assets. Because assignees that perfect by possession or that take delivery as non-ordinary course of business buyers deal with tangible assets physically, considerations are implicated other than 'where to search and register' as in the context of perfection by registration.

As explained above, the location-of-asset STCOL rule provides absolute clarity for perfection by possession. It provides the same clarity as to priority and for the same reason. Moreover, the Modern Principles favour perfection by possession by affording priority to qualifying possessory security rights over those perfected by registration. ${ }^{86}$ When applicable, those priority rules generally relieve the possessory assignee that takes a security right from concerning itself (for example, by searching) with any registration that might have been made. Modern Principles also favour buyers of goods in the ordinary course of business. Such buyers generally take free of a conflicting security right in the seller's inventory. ${ }^{87}$ Although these 'take-free' priority rules may not specify the ordinary course buyer's taking

84

${ }^{85}$ See pp 19-25 above. This discussion assumes, accordingly, that a location-of-assignor STCOL rule applies to perfection by registration for tangible assets.

86 Model Law arts 46(1) (negotiable instruments); 49(1) (negotiable documents); 51(1) (certificated non-intermediated securities); UCC 9-328 (5) (certificated securities); 9-330(a), (b) (chattel paper), (d) (instruments); 9-331 (innocent acquisition under other UCC articles for negotiable instruments, negotiable documents of title, and certificated securities); 9-333 (possessory statutory liens); OPPSA 28(3) (chattel paper), 28(4) (instruments); 28.1(2) (innocent acquisition of certificated securities); 30.1(3) (certificated securities).

87 Model Law art 34(4); UCC 9-320(a), OPPSA 28(1). 
possession as a condition to protection, ${ }^{88}$ it is a safe assumption that the vast majority of ordinary course buyers do in fact take possession of the goods in the course of the transaction. Taking into account this treatment of possessory assignees and ordinary course buyers, a location-of-assignor STCOL rule for the priority of these assignees and buyers would be odd, even incoherent.

Given the assumption of widespread adoption of the Modern Principles, one might expect that in many cases the results of priority contests under priority rules specifically embraced by Modern Principles would be similar under either a location-of-asset or location-of-assignor STCOL rule. But that would not be the case for many other priority contests as to which States have significant interests in the STCOL rules for tangible assets within their borders. For example, putting possession aside, the Modern Principles generally do not dictate the specific requirements for good faith purchaser (innocent acquisition) protection for assignees of negotiable assets. ${ }^{89}$ In addition, there exist a plethora of statutory and common law liens that vary enormously from State to State, relating to, inter alia, environmental claims, assets used in criminal activity, protection of employee claims, assets for which repair services have been performed, the provision of goods and services in connection with agricultural activity, tax claims, and so on. These situations implicate priorities of claims to tangible assets that sometimes may conflict with consensual security rights addressed by the Modern Principles. They involve important public policies of States with respect to assets physically located within their respective jurisdictions. All of these circumstances support the adoption of a location-of-asset STCOL rule for priorities.

\section{Creation}

The creation, or existence, of a security right ${ }^{90}$ might be understood as a two-party, assignor-to-assignee transaction or conveyance. Certainly, the effectiveness of a transfer of a security right as between the parties is the essence or core of the creation of a security right. On the other hand, creation also is a prerequisite for the perfection (third-party effectiveness) of a security right and its priority vis-à-vis competing claims to the same asset. In this latter sense, the interests of third parties, assignors, and assignees in the STCOL rule applicable to the creation of a security right would parallel precisely their respective interests in the STCOL rules affecting perfection and priority. Whether conceptualized as a two-party matter (with third parties having no real stakes in the matter) or a component of the perfection and priority matrix, it is safe to presume that third parties would have little interest in having a STCOL rule applicable to creation that differs from the rule (or respective rules) applicable to perfection and priority. In any event, the appropriate STCOL

88 Possession or possessory rights are an express requirement for qualifying as a 'buyer in ordinary course of business' under the UCC, however. UCC 1-201(9).

89 Cf. Model Law arts 46(2) (negotiable instruments); 49(3) (negotiable documents); 51(5) (nonintermediated securities).

90 Recall that security rights include the interests of outright transferees of receivables. See p 3 above. 
rule applicable to creation has received much less attention, and has attracted much less controversy, than the corresponding rules for perfection and priority.

Consistent with the foregoing, the Model Law generally applies the same STCOL rules for creation as it does for perfection and priority. A location-ofasset rule applies to tangible property and a location-of-assignor rule applies to intangible property. ${ }^{91}$ The Canadian PPSAs take a similar approach to the 'validity' of a security right, which would include (or amount to) creation for purposes of STCOL rules. ${ }^{92}$ Assuming that these STCOL rules adopted by the Model Law and the Canadian PPSAs are the appropriate ones, then the foregoing interest-based and Modern Principles-based analyses of STCOL rules for perfection and priority would apply equally as well to the issue of creation.

UCC Article 9 takes a different approach. The Article 9 STCOL rules are limited to perfection and priority; they do not mention creation or validity. ${ }^{93}$ Consequently, the UCC's generally applicable conflict-of-laws rules, including the broad deference to party autonomy, apply to these issues. ${ }^{94}$ This invites consideration of the multiple components that may be involved in the 'creation' of a security right.

The most basic and obvious component of creation would be the formal requirements for creation specified in the Model Law and under North American law. ${ }^{95}$ In the North American domestic setting, these requirements are essentially identical from State to State and province to province. So the law chosen to apply to creation normally would be inconsequential. ${ }^{96}$ One of the formal requirements is that the assignor 'has rights in the collateral or the power to transfer rights in the collateral ${ }^{97}$ or 'power to encumber' the asset. ${ }^{98}$ One element of this requirement is that the assignor be the right person to effect a transfer-that is, that it is transferring an asset that belongs to it (and not to another) or that it is a person with the power to transfer the asset. A second is that the asset itself be transferable and not be subject to any restriction that would render a purported transfer ineffective. Under the UCC party autonomy approach, it is likely that in

91 Model Law arts 85(1); 86.

92 See, e.g., OPPSA 5(1) (law of jurisdiction of location of asset governs validity as well as perfection and priority for tangible assets); 7(1) (law of jurisdiction of location of debtor governs validity as well as perfection and priority for intangible assets, mobile goods, and negotiable assets).

93 UCC 9-301 et seq. The concept of creation under the UCC involves the 'attachment' of a security interest, which occurs when it becomes enforceable pursuant to the requirements specified in UCC 9-203 (see, in particular, UCC 9-203(b), which specifies the basic requirements). The same applies under OPPSA. OPPSA11(1) (enforceability upon attachment), (2) (requirements for attachment). The text uses the term 'creation' for consistency but it is intended to embrace attachment and enforceability under UCC 9-203 and OPPSA 11.

94 UCC 1-301. See also pre-2001 UCC 1-105.

95 Model Law art 6(1); UCC 9-203(b); OPPSA 11(2).

96 The mutual rights and obligations of an assignor and assignee generally are governed by the law they choose, or by other applicable choice-of-law rules in the absence of such a choice, under both the Model Law and United States law. Model Law art 84; UCC 1-301. But that contractual relationship is a part of 'creation' only in that an agreement is required for creation.

97 UCC 9-203(b)(2); OPPSA 11(2)

98 Model Law art 6(1). 
many circumstances the law chosen by the assignor and assignee to apply to the secured transaction would not be applied to these elements. ${ }^{99}$ The assignor's rights are likely to be derived from a third party in a transaction (for example, in which the assignor bought the asset) that is wholly unrelated to the secured transaction between the assignor and assignee. Similarly, to the extent that the alienability or inalienability of the asset implicates the rights of a third party (such as the third-party obligor on TPO assets), assignor-assignee party autonomy likely would not prevail. ${ }^{100}$ But I would speculate that the same results might well obtain in these circumstances when the Model Law or a PPSA is the governing law. The law of the State of the assignor's location (in the case of intangible assets) or the location of the asset (in the case of tangible assets) also plausibly would not be controlling. For TPO assets, the law governing the intangible (such as the claim constituting a receivable) likely would control.

The harmony of law among the States renders the UCC's party-autonomy approach to creation largely benign. The approach taken by the Model Law and the Ontario PPSA seems more promising and appropriate for States other than those of the USA. ${ }^{101}$ The creation of a security right is the fulcrum upon which rests third-party interests affected by perfection and priority rules. This supports adoption of the more objectively ascertainable location-of-asset and location-of-assignor STCOL rules. Even so, when the STCOL rule for creation is compared to the rules for perfection and priority, the stakes are quite low.

\section{Enforcement}

\section{A. Against assets and assignor}

The Model Law contains a STCOL rule that addresses specifically the enforcement ${ }^{102}$ of a security right in assets. For tangible assets, the applicable law is that of the location of the asset at the time that enforcement commences. ${ }^{103}$ For intangible assets, it is the law applicable to priority-the assignor's location. ${ }^{104}$ Other than the temporal component for tangible assets, these rules essentially mimic the rules for creation, perfection, and priority. As with the creation issue, the UCC's generally applicable conflict-of-law rules apply to enforcement, thus accommodating party autonomy. ${ }^{105}$ The PPSAs take the same approach as the UCC, referring to the law of the assignor-assignee contract. ${ }^{106}$

99 See UCC 9-401, comment 3 (explaining limits on party autonomy and applicability of non-UCC law).

100 Ibid.

101 See p 30 above.

102 The enforcement of a security right should be distinguished from its enforceability, which generally is an attribute of creation or validity.

103 Model Law art 88(a). An exception is made for certificated non-intermediated securities, discussed below.

104 Ibid art 88(b). Exceptions are made for bank accounts, intellectual property, and uncertificated non-intermediated securities.

105 See p 30 above.

106 OPPSA s 8(1)b) (substantive issues). As to procedural issues, the law of the jurisdiction where enforcement is exercised applies. Ibid s $8(1)(\mathrm{a})$. 
These rules generally parallel the respective rules applicable to creation. ${ }^{107}$ For this reason, they would meet the bilateral interests of assignors and assignees; party autonomy as to the applicable law would in general accommodate and not necessarily impair the interests of either party. But enforcement of a security right against an encumbered asset also may have a direct effect on the interest of third parties. For example, a junior interest may be extinguished by the enforcement of a senior interest and the extinguishment of an assignor's interest may have a direct impact on the welfare of the assignor's general creditors. ${ }^{108}$ It follows that the STCOL rules under the Model Law that generally follow the rules for perfection and priority would better meet the interests of third parties.

\section{B. Against third-party obligors}

The STCOL rule applicable to the enforcement of a security right against a thirdparty obligor (which includes the effectiveness of the interest as against the obligor) is a core principle of any coherent STCOL regime. The Model Law addresses these issues well by generally respecting overarching applicability of the law governing the rights and obligations between third-party obligors and assignors. ${ }^{109}$ That governing law applies to the rights and obligations between third-party obligors and assignees, the conditions for enforcing a security right against third-party obligors, including the effectiveness of any contractual restriction on creation of a security right, and the discharge of obligations of third-party obligors. North American law generally is in accord. ${ }^{110}$

The upshot of these STCOL rules is that the assignment of TPO assets and the perfection and priority status of a security right so created would not enlarge or enhance the obligations of a third-party obligor beyond those that would apply by virtue of the obligor's underlying contract ${ }^{111}$ and the otherwise applicable governing law. It follows that a third-party obligor would be indifferent as to perfection (for example, the rights of judgment creditors and the assignor's insolvency representative) or priority (which party, among competing claimants, is entitled to benefits of the obligor's obligations and to the enforcement against the obligor). The third-party obligor's obligations arise only under its contract

107 See pp 30-31 above.

108 See e.g., Model Law art 78(4) (notification to certain persons of disposition of collateral after default); 81(4) (disposition discharges subordinate interests); UCC 9-611 (notification to certain persons of disposition of collateral after default); 9-617(a)(3) (disposition discharges subordinate interests); 9-618 (secondary obligors); OPPSA s 63(4) (notification to certain persons of disposition of collateral after default), (9) (disposition discharges subordinate interests).

109 Model Law art 96. Article 96 applies to third-party obligors on receivables, negotiable instruments, and negotiable documents. Although it does not cover obligations of issuers of securities, discussed below in subsection III.5. Model Law Article 100 provides a similar result.

110 See UCC 9-401, comment 3 (discussing issues, including restrictions on transfer, governed by non-UCC law and not subject to party autonomy); 9-404 (third-party obligor's defenses against assignee), 9-406 (discharge of third-party obligor); OPPSA 40(1.1) (third-party obligor's defenses against assignee), (2) (discharge of third-party obligor).

111 For shorthand convenience references to the underlying 'contract' in this discussion include the obligations of an obligor on a negotiable instrument or as an issuer of a negotiable document. 
and the law applicable to that contract. It follows that such obligors would not only be indifferent as to perfection and priority but also as to the STCOL rules for perfection and priority. Thus, these obligors would be indifferent as between a law-governing-claim or location-of-assignor STCOL rule for perfection and priority as to assigned intangibles, inasmuch as obligations of the third-party obligor would be the same regardless of which of those STCOL rules were to apply. If a third-party obligor is bound to pay or render performance to an assignee, it is because the underlying contract, the law applicable to that contract, or both impose such an obligation.

\section{The Model Law's choice-of-law rule for certificated non-intermediated securities: a puzzle and some lessons}

The Model Law's STCOL rule for certificated non-intermediated securities ${ }^{112}$ took shape only at the very end of the process. The inclusion of that rule offers an object lesson for a faulty process in the harmonization of law, notwithstanding the good faith of its proponents. But the origin of the problem remains a puzzle. Article 100's approach is inconsistent with the other important choice-of-law principles enshrined in the Model Law and embodied in North American law. Happily, if adopted by States it likely would have only a minimal detrimental impact in the practical, transactional context. One is reminded of Grant Gilmore's famous commentary on the exclusion of set-off from the scope of Article 9 of the UCC: 'Of course a right of set-off is not a security interest and has never been confused with one: the statute might as appropriately exclude fan dancing.... $[\mathrm{T}]$ he exclusion ... does no harm except to the dignity and self-respect of the draftsmen.' ${ }^{\prime 13}$

Some background may be useful. The draft Guide excluded all securities from its scope. This was in large part because during the draft Guide's formative period intermediated securities were being addressed by International Institute for the Unification of Private Law (UNIDROIT) in connection with a project that resulted in the adoption in 2009 of the Geneva Securities Convention, which covers 'intermediated securities'. ${ }^{114}$ Non-intermediated securities were included within the scope of the draft Model Law rather late in the deliberative process of the United Nations Commission on International Trade Law's (UNCITRAL) Working Group VI. ${ }^{115}$ Consequently, the draft Guide itself offers no illumination or background concerning the Model Law's ultimate treatment of securities,

112 Model Law art 2(d) (defining '[c]ertificated non-intermediated securities' as 'non-intermediated securities represented by a certificate that: (i) Provides that the person entitled to the securities is the person in possession of the certificate; or (ii) Identifies the person entitled to the securities'. 'Non-intermediated securities' are 'securities other than securities credited to a securities account'. Ibid art 2(w).

1132 Grant Gilmore, Security Interests in Personal Property (1965) s. 10.7, 315-16.

114 Unidroit Convention on Substantive Rules for Intermediated Securities (Geneva Securities Convention) 2009 (Geneva), http://www.unidroit.org/instruments/capital-markets/geneva-convention, art 1(2) (defining 'intermediated securities').

115 Report of Working Group VI (Security Interests) on the Work of its Twenty-Seventh Session (New York, 20-4 April 2015) at 3, https://documents-dds-ny.un.org/doc/UNDOC/GEN/V15/ 
including its relevant STCOL rules. Had security rights in non-intermediated securities been the subject of careful analysis and debate in the process of developing the draft Guide, perhaps Article 100 would not exist in its present form, if at all.

Certificated non-intermediated securities, like other negotiable assets (negotiable instruments and negotiable documents) ${ }^{116}$ and goods are 'tangible assets' as defined in the Model Law. ${ }^{117}$ As such, perfection may be achieved either by registration or possession. ${ }^{118}$ As discussed above, the Model Law adopts a location-of-asset STCOL rule for tangible assets but provides an exception (among other exceptions) for certificated non-intermediated securities. ${ }^{119}$ Article 100(1) of the Model Law provides for equity securities: 'The law applicable to the creation, effectiveness against third parties, priority and enforcement of a security right in non-intermediated equity securities, as well as to its effectiveness against the issuer, is the law under which the issuer is constituted. ${ }^{120}$ Article 100(2) provides, for debt securities, that the applicable law for the same matters is the law governing the securities'. ${ }^{121}$

Certificated non-intermediated securities are a type of TPO asset (the issuer being the third-party obligor). ${ }^{122}$ As such, the "law under which the issuer [of equity securities] is constituted' and the 'law governing ... [debt] securities', the applicable laws provided by article 100, are analogous and equivalent to the law governing a claim (such as a receivable). As explained above, a law-governingclaim STCOL rule is suboptimal for the interests of third parties, assignors, and assignees for perfection by registration and priority for intangible TPO assets, such as receivables. ${ }^{123}$ Given this, why would the law-governing-claim STCOL rule imposed by Article 100 be suitable for perfection by registration and priority of security rights in certificated non-intermediated securities? ${ }^{124}$ The rule bears

029/20/PDF/V1502920.pdf?OpenElement. The Model Law expressly excludes from its scope intermediated securities. Model Law art 1(3)(c).

116 The Model Law uses the terms 'negotiable instrument(s)' and 'negotiable document(s)' but does define either term. See, e.g., Model Law art 2(ll) (defining 'tangible asset').

117 Ibid.

118 Model Law art 18.

119 Model Law art 85(1).

120 Model Law art 100(1).

121 Ibid art 100(2). As already explained, Article 98 of the Model Law provides for a location-of-assignor STCOL rule for perfection by registration in negotiable assets if the law of the State of the assignor's location provides for perfection by registration for such assets. See p 24 above. But what if the law of the assignor's State does not so provide? In that case, one might have expected that the Model Law's generally applicable STCOL rule for tangible assets-the location-of-asset rule under Article 85(1) — should apply. However, because Article 85(1) makes an exception for Article 100, that article provides the general STCOL rule for perfection (whether by registration or by possession) for non-intermediated securities.

122 See Introduction and section II.2.D in this article for a discussion of TPO assets.

123 See pp 15-17 above.

124 If the law of the State of an assignor's location does not provide for the perfection of security rights in certificated non-intermediated securities by registration in the security rights registry, Article 100 's law-governing-claim rule applies to perfection by registration (as well as by possession). 
no relationship to, or connection with, searching and registration in an assignor identifier-based registry or any priority rules based on such registration. ${ }^{125}$

Consider also perfection by possession for certificated non-intermediated securities. For perfection by possession and priority for tangible assets, whether goods or negotiable assets, the clear superiority of the location-of-asset STCOL rule also was explained above. ${ }^{126}$ Based on that discussion, the Article 100 law-governingclaim STCOL rule for certificated non-intermediated securities is anomalous, to say the least, for possessory perfection and priority in such tangible assets. It is noteworthy that under the Model Law certificated non-intermediated securities are the only type of tangible asset for which a location-of-asset STCOL rule does not apply for perfection and priority. For tangible assets, Article 9 of the UCC applies the location-of-assignor rule to perfection by registration ${ }^{127}$ but applies the location-of-asset rule to perfection by possession and to priority. ${ }^{128}$ For tangible assets under the PPSAs, the location-of-asset rule applies to both perfection and priority. ${ }^{129}$ None of these modern regimes adopts an article 100-type lawgoverning-claim STCOL rule for perfection and priority for any type of tangible asset-save only the Model Law's Article 100 rule for certificated non-intermediated securities. And all of these modern regimes, excepting Article 100, provide for a location-of-asset STCOL rule for perfection by possession and priority for tangible assets, including certificated non-intermediated securities.

The foregoing presents the puzzle of Article 100: what is its rationale? Did the process of deliberating, negotiating, and drafting the Model Law reveal something about certificated non-intermediated securities that is materially different from other tangible assets (which includes close cousins that reify intangibles and goods, negotiable instruments and negotiable documents) and that the drafters of North American law have missed? Apparently not - at least based on the record discussed below. ${ }^{130}$ The location-of-assignor STCOL rule for perfection by registration in an assignor-identifier-based secured transactions registry and the location-of-asset STCOL rule for perfection by possession of tangible assets each bears a coherent relationship to those methods of perfection and the related priority rules. Each serves the interests of third parties, assignors, and assignees. However, the Article 100 law-governing-claim STCOL rule for certificated non-intermediated securities has no coherent relationship to those methods of perfection,

Concerns about bulk assignments, future arising assets, and suitability for international, cross-border transactions may be less pronounced in the context of certificated non-intermediated securities than in the case of assignments of receivables. See pp 15-17 above. But this would hardly seem sufficient to justify the law-governing-claim STCOL rule of Article 100. Moreover, I am unaware that anyone has argued that these differences would support such a rule.

125 Ibid.

126 See pp 25-26, 28 above.

127 UCC 9-301(1).

128 UCC 9-301(2) (perfection and priority for possessory security interests), (3)(C) (priority for non-possessory security interests).

129 OPPSA 5(1).

130 See pp 39-41 below. 
even though these are the only two methods of perfection for those assets under the Model Law. The Article 100 rule simply ignores the important connection between the appropriate STCOL rule and the public notice function of perfection (and the relationship between perfection and priority).

One plausible solution to the puzzle of Article 100 (perhaps the most promising one) may inhere in the connection between the law governing securities (the Article 100 standard) and the commercial practices and expectations of assignors and assignees of certificated non-intermediated securities (or, at least, some of them). First, that law would be implicated in the determination of whether a nonintermediated security is certificated security, a type of tangible asset, or an uncertificated security (as to which Article 100's law-governing claim STCOL rule clearly is appropriate, as discussed below ${ }^{131}$ ). It is a reasonable assumption that, putting the Model Law's STCOL rules aside, the law governing TPO assets would be the most appropriate one for such a characterization of securities as well as for their alienability and for methods of third-party effectiveness. ${ }^{132}$ The characterization of securities as certificated under the Model Law turns on whether the securities are 'represented by a certificate that: (i) Provides that the person entitled to the securities is the person in possession of the certificate; or (ii) Identifies the person entitled to the securities'. ${ }^{133}$ When does a certificate so 'represent[]' securities?

By taking this definition and a process of 'reverse engineering' based on the Model Law's rule permitting perfection in tangible assets (including certificated non-intermediated securities) by possession, it is fair to infer (and conclude) that securities are certificated if (i) delivery (possession) of the certificate relating to the securities is or may be a material element in the effective transfer of the securities and (ii) the certificate itself so indicates. This understanding of certificated non-intermediated securities does not exclude the possibility that under the law governing the securities effective transfers could be made without delivery (possession), as by registration in a security rights registry, or that steps in addition to a delivery might be required for an effective transfer - such as registration on the issuer's register or notification to the issuer of the transfer-a 'possessionplus' effectiveness rule. ${ }^{134}$ But this understanding would contemplate that, while a

131 See p 40 below.

132 See the discussion above of the creation of a security right and the alienability of assets. See pp 30-31 above.

133 Model Law art 2(d) (emphasis added). If the securities are not so represented by a certificate, they are uncertificated. Ibid art $2(\mathrm{~mm})$.

134 One might take a more narrow view of certificated securities under which they would include only securities that, under the law governing the securities, a delivery-related transfer effective against third parties may be made by delivery (possession) alone. That approach would mean that securities subject to a 'possession-plus' rule would be uncertificated securities. Under that interpretation, the Model Law would provide that (i) certificated securities (as defined in Model Law Article 2(d)) include only those as to which possession is the sole method of possession-related perfection and (ii) under Model Law Article 18(2) possession is an applicable method of perfection. Such an interpretation would render the Model Law's perfection rule for certificated securities both circular and superfluous. 
person is in possession, that possession would preclude the effective transfer to another person by delivery (possession).

Second, consider as well practices concerning registered certificated non-intermediated securities - those as to which the certificate identifies a person entitled to the securities and the issuer maintains a register of such entitled persons. ${ }^{135} \mathrm{In}$ some situations, an assignee may interact directly with the law governing securities by becoming the registered holder of the securities on the issuer's register. As Example 1, assume that the assignee chooses to do so in order to control voting rights or to ensure collection of distributions, such as dividends. In Example 2, the assignee chooses to become the registered holder (or 'pledgee') because under the law governing the securities that registration is necessary, in addition to the delivery (possession) of security certificate, for the effectiveness of the assignment against third parties - that is, pursuant to a 'possession-plus' perfection rule. ${ }^{136}$ These practical connections between an assignee and the law governing certificated non-intermediated securities are evocative of the argument, discussed above, that a law-governing-claim STCOL rule is appropriate for perfection of assignments of intangibles (such as receivables) because during the course of a transaction a prospective assignee must consult the law governing a claim (here, the law of the issuer of securities) in any event. ${ }^{137}$

This argument was adequately rebutted above in the discussion of assignments of receivables. ${ }^{138}$ That rebuttal need not be repeated here. But, in the present context of registered securities, the argument may have a greater appeal (but only superficially) because of the posited direct and substantive connection between the assignee and the issuer's register of securities holders. The appeal is superficial, however, because on closer examination it reflects an analytical laziness and a fundamental misunderstanding of the relevant Model Law rules on perfection and priority and the related STCOL rules.

In Example 1, the assignee's wish to obtain protections as to voting and dividends through issuer registration has nothing to do with its perfection by taking physical possession of the certificated securities located in a jurisdiction that has no necessary connection with the law governing the securities. That prophylactic procedure (issuer registration) is functionally equivalent to an assignee of a receivable notifying the debtor of the receivable to remit payment directly to the assignee, a step that also is wholly unrelated to perfection and priority. ${ }^{139}$ The issue in question is the appropriate STCOL rule under the Model Law for the assignee's perfection of its security right by taking possession of the certificated

135 This potential 'solution' would not support or explain the Article 100 approach for bearer securities, however.

136 See, e.g., Laws of Cyprus (1959), ch. 149, Contract, art 138(2) (valid and enforceable pledge of shares requires, inter alia, (i) notice of pledge to issuer, (ii) memorandum of pledge in issuer's register of shareholders, and (iii) delivery by issuer of memorandum of pledge made in register.

138 Ibid.

139 See Model Law art 63(2) (debtor of the receivable discharged only by paying the assignee following notification to that debtor of the assignment of the receivable to the assignee). 
security in the jurisdiction in which the certificate is physically located. As with other tangible assets, the location-of-asset STCOL rule is the appropriate one for perfection and priority of possessory security rights. ${ }^{140}$ While the location of an issuer or its register may sometimes have been a proxy for fictionalizing a situs for registered securities, ${ }^{141}$ under the Model Law perfection is achieved by possession of the actual physical certificate, not by registration at a fictional location based on the location of the issuer or its register.

Now consider Example 2, in which the law governing the securities provides that registration on the issuer's register is necessary, in addition to the delivery (possession) of the security certificate, for third-party effectiveness (a 'possessionplus' perfection rule). If a real-life assignee perceives (as it often might) that in the event of a dispute or enforcement a plausible forum would be a court in the issuer's jurisdiction or any forum court with a STCOL rule that would apply the law governing the security to perfection and priority, then the assignee might well choose to become the registered holder so as to ensure perfection were that law to be applied. Once again, however, these circumstances do not support the adoption in the Model Law (or by any State, for that matter) of a STCOL rule such as Article 100 that would point to the law of the issuer's jurisdiction for perfection and priority. The Model Law has rejected, on the merits, a possession-plus perfection rule and opted instead for a possession-only rule. ${ }^{142}$ The issue is the appropriate Model Law STCOL rule to govern perfection by possession of certificated non-intermediated securities. The fact that in the real world some assignees prudently choose to comply with possession-plus perfection rules of issuers' jurisdictions as a practical measure does not bear on the appropriate STCOL rule for the Model Law or otherwise for States to adopt.

The approach of Article 100 recognizes that for some assignees in some circumstances compliance with the (suboptimal, according to the Model Law) possession-plus perfection requirements of the law governing the securities may not be inconvenient. But it fails to recognize that such compliance may be quite inconvenient for other assignees that wish merely to take possession of certificates located in a jurisdiction with the Model Law's method of perfection by a possession-only rule. Even in a forum sitting in a State that has adopted the Model law and for certificated securities located in that State, Article 100 could require that forum to apply a possession-plus perfection rule that the Model Law itself has rejected! This illustrates the disconnect between the Model Law's possession-only perfection rule and the Article 100 law-governing-claim STCOL rule.

140 See pp 25-26, 28 above.

141 See Roy Goode, Hideki Kanda, and Karl Kreuzer, Hague Securities Convention Explanatory Report (2005) 17.

142 The Model Law is replete with examples of alternative approaches, thus recognizing that adopting States reasonably may make differing policy choices within the general parameters of the Modern Principles as embodied in the Model Law. See, e.g., Model Law, ch IV (Model Registry Provisions), arts 13 (Options A and B); 14 (Options A, B, and C); art 97 (Options A and B). But the Model Law does not include any such possession-plus perfection rule, even as an alternative. 
Is there an explanation for the Article 100 puzzle that is not subject to the superficial appeal criticized above? Perhaps so, but it also is unsatisfying from the perspective of the Model Law. Perhaps the root of the support for the Article 100 approach is the view that a superior perfection rule would be a possessionplus rule that requires not only possession but also registration of the assignment in the issuer's register. On the merits, at least, this position would make some sense. After all, if there are good reasons for some assignees to comply with issuer registration in any event (such as in Examples 1 and 2 discussed above), why not adopt possession-plus-registration as the applicable perfection rule? I will not dwell on the reasons (of which there are many) for rejecting such a rule, including the additional burdens that it would place on assignees acquiring possessory security rights. ${ }^{143}$ Suffice it to note that the Model Law has itself rejected such a rule by adopting a possession-only perfection rule. ${ }^{144}$

Article 100 also cannot be rationalized based on concerns for the interests of issuers of certificated non-intermediated securities as third-party obligors. As explained above, these concerns are dealt with adequately by the law-governing-claim rule that applies to the issuers' obligations. ${ }^{145}$ The relevant STCOL rules and the methods of perfection and priority rules that regulate who is ultimately entitled to the securities do not affect or impair the rights and obligations of the issuers or the enforceability of certificated non-intermediated securities against issuers. It follows that the issuers should be indifferent as to the STCOL rules for perfection and priority.

Assets that are intangible and not represented by a res (such as a security certificate) include bank accounts, uncertificated securities, intermediated securities, and securities accounts. For these intangible assets, a law-governing-claim STCOL makes sense for perfection (other than perfection by registration in the security rights registry) and priority. ${ }^{146}$ For example, under the Model Law perfection for uncertificated securities may be achieved by notation or entry on the books of the issuer or pursuant to a control agreement. ${ }^{147}$ Similar methods are provided under North American law. ${ }^{148}$ In general, these methods recognize that

143 Even if many, or even most, assignees seek such issuer-register protections (which I suspect is highly unlikely), such a perfection rule would force many other assignees to deal with the issuer's books instead of simply taking possession of certificates under the Model Law's possession-only perfection rule.

144 In an analogous context, the Geneva Securities Convention was emphatic as to its 'credit-only' transfer rule. See Geneva Securities Convention (n. 114), art 11(1), (2) (emphasis added): '[I]ntermediated securities are acquired by an account holder by the credit of securities to that account holder's securities account. ... No further step is necessary, or may be required by the non-Convention law or any other rule of law applicable in an insolvency proceeding, to render the acquisition of intermediated securities effective against third parties.'

145 See pp 31-32 above.

146 As noted above, the Article 100 general rule applies, quite inappropriately, to perfection by registration when the assignor is not located in a State the law of which provides for perfection in securities by registration. See p 34 above.

147 Model Law art 27; see section II.2.C concerning other methods of perfection.

148 UCC 9-305(a)(2) (law of issuer's jurisdiction governs perfection and priority for uncertificated security); OPPSA 7.1(2) (law of issuer's jurisdiction governs perfection and priority for uncertificated security). 
the issuers, intermediaries, and depository banks are the best 'scorekeepers' for claims to and against these assets (again, putting aside registration in the security rights registry). For these assets, Article 100, the Hague Securities Convention, and North American law appropriately apply the law-governing-claim STCOL rule. $^{149}$

Working Group VI last considered the conflict-of-laws provisions of the draft Model Law in October 2015. Draft Article 93, then before the Working Group, provided three alternatives for certificated non-intermediated securities. ${ }^{150}$ Alternative A provided the usual rule for perfection and priority for tangible assets-the location of the certificate. ${ }^{151}$ Alternative B provided that creation, perfection, priority, enforcement, and effectiveness against the issuer would be governed by the law 'under which the issuer is constituted.' Alternative $\mathrm{C}$ was essentially the same as Article 100 as ultimately adopted-adopting the Alternative B formulation for equity securities but substituting 'the law governing the securities' for debt securities.

The principal advocate for the substance of Option $\mathrm{C}$ during the Working Group deliberations was the Commercial Finance Association (CFA). ${ }^{152}$ The CFA argued that (i) Alternative A was too complex, artificial, and unrealistic (but without offering explanations for these conclusions); ${ }^{153}$ (ii) while Alternative B was the simplest rule, it inappropriately gave identical treatment to equity and debt securities; and (iii) Alternative C, consequently, was preferred based on simplicity and efficiency. It also argued that the location-of-asset rule for certificated non-intermediated securities would permit the 'manipulation' of the applicable law. Some other delegations pointed out that Alternative A's adoption of the location-of-asset STCOL rule was consistent with the treatment for negotiable instruments and negotiable documents, was most likely to attract a

149 Convention on Law Applicable to Certain Rights in Respect of Securities held with an Intermediary, 2006 (The Hague), https://assets.hcch.net/docs/3afb8418-7eb7-4a0c-af85c4f35995bb8a.pdf, art 4(1) (law governing account agreement governs, inter alia, perfection and priority for intermediated securities); UCC 9-304(1) (law of bank's jurisdiction governs perfection and priority for deposit accounts); 9-305(3) (law of securities intermediary's jurisdiction governs perfection and priority for security entitlements and securities accounts); OPPSA (law of securities intermediary's jurisdiction governs perfection and priority for security entitlements and securities accounts).

150 Draft Model Law on Secured Transactions art 93, A/CN.9/WG.VI/WP.65/Add.4, 12-14 (28 July 2015) (July 2015 Draft).

151 It also provided that the same rule would apply to creation, that enforcement would be governed by the law of the State where the act of enforcement occurs, and that the effectiveness of a security right against the issuer would be governed by the law of the State of the constitution of the issuer. Ibid.

152 UNCITRAL, Working Group VI, audio recording (16 October 2015) (October Recording), http://www.uncitral.org/uncitral/audio/meetings.jsp. The discussion that follows is based on this recording.

153 For certificated non-intermediated securities, Alternative A provided that (i) creation, perfection and priority is governed by the law of the location of the security certificate, (ii) enforcement is governed by the State in which enforcement takes place, and (iii) the effectiveness of a security right against the issuer is governed by the law of the State of the issuer's constitution. These are essentially equivalent to the rules applicable under that same draft for other tangible assets and third-party obligors. July 2015 Draft (n. 150), arts 79(1); 82(a); 89(a). Given that, the CFA's characterizations are puzzling. 
consensus in a model law, reflected a pragmatic and well-known rule, and would not undo progress already made. ${ }^{154}$ But, in the end, the USA's suggestion-that all alternatives received some support and should be retained-carried the day. ${ }^{155}$ The draft submitted to UNCITRAL in July 2016 contained all three alternatives. $^{156}$

The deliberations leading to UNCITRAL's adoption of Alternative C of the Draft Article 97 (now Article 100) are particularly opaque as to substance. The entire floor discussion of the article occupied only slightly more than four minutes' time. ${ }^{157}$ Canada led by noting that notwithstanding its written comments it supported Option C and the deletion of Options A and B. By way of explanation, it noted that its change of position demonstrated 'the purpose of informal consultations' in the evolution of views of delegations. The USA, Spain, the CFA, and the United Kingdom followed suit. The deed was done. Canada's reference to consultations and the CFA's expression of gratitude for the evolved views of delegations (that is, support for Alternative C) offers a hint as to motivations but offers no glimpse of the underlying substance. ${ }^{158}$ The CFA's intervention repeated its earlier assertions of simplicity, promotion of uniformity, and the like. Most remarkably, however, the CFA also asserted that the location of a security certificate bears no relation to the relevant transaction-quite an astounding proposition inasmuch as a principal issue was the STCOL rule for perfection by an assignee's physical possession of the certificate.

This subsection of the article has digressed from its otherwise policy-oriented and technical approach to consider the lessons learned from the saga of Article 100. What are the lessons? First, one hopes that had the discussions embraced something like the interest-based and Modern Principles-based framework advanced here, perhaps the clear disconnect between the Article 100 approach, on the one hand, and the Model Law's rules on perfection by registration, perfection by possession, and priority, on the other, would have produced a different result. But perhaps a frank confrontation of the merits was never in the cards. During the deliberations on the STCOL rule for certificated non-intermediated securities, the proponents of the Article 100 law-governing-claim rule never explained why the rule for those assets should differ from the rule for other tangible assets, including negotiable instruments, negotiable documents, and goods. Nor was any explanation forthcoming as to why the rules for those other assets should

154 October Recording, interventions of Canada, France, Switzerland, and Korea.

155 October Recording, intervention of United States.

156 Draft Model Law on Secured Transactions art 97, A/CN.9/884/Add.4, 7-8 (17 March 2016). Alternative A of that draft was modified to include alternative paragraphs contemplating the possibility of different treatment for debt securities, similar to that provided in Alternative C.

157 UNCITRAL, 49th Session, audio recording (29 June 2016), http://www.uncitral.org/uncitral/ audio/meetings.jsp. The discussion that follows is based on this recording.

158 Shortly after the UNCITRAL meeting I consulted with representatives of two expert delegates of prominent States, who participated in the meeting, as to how and why Article 100 had emerged. One explained that it resulted from 'effective and powerful lobbying' and another was surprised and unaware of what had transpired during the four-plus minutes of discussion. 
not be conformed to the Article 100 approach. If there are good reasons for these differences, one wonders why they were not mentioned on the record during the process. This sparse record, especially when considered with the off-the-record, apparently outcome-determinative consultations mentioned on the record, reflects poorly on the intergovernmental harmonization process. But this should not detract from the overall success and high quality of the Model Law project.

A second lesson learned is procedural. It is the need to encourage a clear and more complete record of a harmonization project, especially when it deviates sharply from principles that it otherwise embraces-here, the Model Law's STCOL rules. Article 100 reflects an abject failure of transparency in the process of reform and harmonization of law. A third lesson is substantive and related to the second. It is the need to adopt a coherent framework for assessing STCOL rules, such as the framework proposed here. The incoherence of Article 100 reflects the importance of recognizing and heeding the necessary connections between rules on perfection and priority and the corresponding STCOL rules.

This story of Article 100 concludes on three happier notes. First, the Model Law is just that. It is not a real law, and it is not a convention. It is doubtful that States actually will adopt the Article 100 approach. Second, the Article 100 approach did not infect the other STCOL rules for tangible assets, which generally are salutary. Third, even if adopted by States, Article 100 likely would have very little practical effect. I suspect that in the vast majority of circumstances the applicable law under that provision and under a conventional location-of-asset STCOL rule would be the same. Securities that are traded actively on exchanges and other trading platforms today are largely intermediated securities that are dematerialized or immobilized within a central securities depository. Certificated securities to which Article 100 would apply typically are issued by small- to medium-sized enterprises and closely held or else are issued by subsidiaries and affiliates forming parts of corporate groups (including multinational enterprise groups). In these situations, the locations of the certificates and the applicable law under Article 100 are likely to converge. Unfortunately, this is not necessarily so. Were it adopted, Article 100 's incoherence could yet harbour mischief.

\section{Conclusion}

This article has proposed, applied, and tested a framework for assessing STCOL rules. The framework for assessment suggested here takes account of the interests of the relevant stakeholders (third parties in general, assignors, assignees, thirdparty obligors on TPO assets, and States) together with the emerged and emerging Modern Principles. In advocating for this interest-based, Modern Principlesbased framework, I do not suggest that earlier commentary and law reform efforts generally have failed to consider the relevant interests and principles of secured transactions law or generally have reached conclusions and supported STCOL rules that reflect bad public policy. I do claim, however, that earlier assessments and developments of STCOL rules could have benefited from a more systematic 
approach towards a statutory dépeçage that takes into account, in particular, the relationships between STCOL rules and the relevant components of secured transactions law_creation, perfection, priority, and enforcement (against assignors and third-party obligors).

Taking the Model Law as its exemplar, the article considers how the application of the framework might have facilitated a richer, more nuanced approach to the Model Law's STCOL rules. In particular, application of the framework might have resulted in a different approach for perfection by registration in tangible assets (a location-of-assignor rule as opposed to the Model Law's generally applicable location-of-asset rule). And it almost certainly would have identified a STCOL rule quite differently from Article 100 for perfection and priority for certificated non-intermediated securities. But I should reiterate the point made in the introduction; this application of the interest-based and Modern Principles-based framework and the resulting conclusions necessarily are based on the factual assumptions and judgments that I have made as to the various stakeholder interests and the impact of STCOL rules on those interests and on the implementation of the Modern Principles. In that connection, my chief assertion is the utility and suitability of the framework for assessment proposed here, not the conclusions that I have reached.

UNCITRAL should (quite deservedly) bask in the success of completing the text of its Model Law. But we should appreciate, and anticipate, that secured transactions law may yet experience radical transformations in the twenty-first century-some currently imaginable and some not so. New technologies may transform the field. These may include distributed ledger technology (that is, 'blockchain'), new self-contained systems within which assets are created and identified and interests in assets are transferred and extinguished, and the development of international and multinational registries. ${ }^{159}$ These and other developments will challenge conventional thinking and call into question past approaches to secured transactions law, including the STCOL rules. Perhaps this article will provide some beneficial insights along the way.

159 See generally Charles W Mooney, Jr, 'Fintech and Secured Transactions Systems of The Future' (2017) 81(1) Law and Contemporary Problems (forthcoming); Teresa Rodríguez de las Heras Ballell, 'Digital Technology-Based Solutions for Enhanced Effectiveness of Secured Transactions Law: The Road to Perfection?' (2017) 81(1) Law and Contemporary Problems (forthcoming). 